$\xi^{2}=1$

\title{
Diagenesis and reservoir quality evolution of the paleogene sokor1 sandstones in the Agadem block, Termit basin, eastern Niger
}

\author{
HAMMA ADA Moussa ${ }^{1 *}$, HAROUNA Moussa ${ }^{1}$ \\ ${ }^{1}$ Department of Geology, Abdou Moumouni University of Niamey/Niger, BP: 10662 Niamey, 8000-Niger \\ *Corresponding author E-mail: hammamoussa@gmail.com
}

\begin{abstract}
The Paleogene Sokor1 Formation in Termit Basin is recognized as the most important hydrocarbon reservoir. However, in spite of its reservoir importance, published studies on its diagenetic process and their effects on reservoir quality are absent or limited. Petrographic analysis, scanning electron microscopy and X-ray diffraction were used to assess diagenetic characteristics, controls on reservoir and reservoir quality of Sokor1 Formation. The Sokor1 sandstones are mostly quartz sandstone, lithic quartz-arenite and rarely lithic fedspathic-quartz-arenite, with an average mass fraction of quartz 95\%, feldspar 1.6\% and rock fragments 3.4\% (Q95F1.6R3.4). Diagenetic processes in Sokor1 sandstones include mechanical compaction, cementation, dissolution and replacement. The main authigenic minerals are quartz overgrowth and clay minerals, which occur as pore-filling and pore-lining cements. Sokor1 sandstone has undergone stages A and B of eodiagenesis and now, it is experiencing stage A of mesodiagenesis. The widespread occurrences of quartz overgrowth suggest that Sokor1 sandstones lost a significant amount of primary porosity during its diagenetic history. Secondary porosity occurred due to partial and complete dissolution of feldspar, quartz grains and rock fragments, so increasing reservoir quality. The latter is predominantly controlled by depositional environment controls on grains size, sorting and matrix. Thus, reservoirs of best quality were deposited in braided river channel environments. In addition, oil accumulation has no discernable effects on porosity and oil probably entered the reservoir at late diagenetic stage, after quartz overgrowth and authigenic cements had already occurred.
\end{abstract}

Keywords: Dissolution; Illite-Smectite Ratio; Reservoir Quality; Sandstone Diagenesis; Termit Basin.

\section{Introduction}

The Termit Basin is a typical Mesozoic-Cenozoic intracontinental Rift basin, part of the Eastern Niger Basins within the West African System. The later with the Central African Rift System form the so-called West and Central African Rift system (Fairhead 1986, Schull 1988, Genik 1992, 1993).This rift system originated during the break-up of the Gondwana land and the forming of the South Atlantic and Indian Oceans in the Early Cretaceous time. Located at the southeastern side of the country, about 1400km East of Niamey (the capital of Niger), between latitude $12^{\circ}$ and $17^{\circ} \mathrm{N}$ and longitude $12^{\circ}$ and $16^{\circ} \mathrm{E}$ (Fig.1). It connects with narrow grabens (Fig.1), namely Tefidet, Tenere, Grein, Bilma and Kafra grabens to the North and adjoins the Bornu Basin at the northern end of Benoue fault zone and Chad Basin to the South. To the West and North-West it is bounded by crystalline basement rocks of Goure and Air Mountain and Mesozoic Zinder massifs. To the East and North-East the Mesozoic Dibeilla granite constitutes the border (Genik 1992).

The Termit is an extensional asymmetric Rift Basin and contains estimated sediment thickness of around 12,000m (Genik 1992, 1993). In Niger, oil exploration began in 1950's years and the first 20 years was consisted mainly of reconnaissance surveys in the southern Hoggar, Djado, Talak, Lake Chad zone and the southern Iullemmeden Basin. In 1982, well Sokor-1 encounter oil in the Paleogene Sokor1 Formation at the western part of the Termit Basin. For more details of oil exploration history, readers are referred to Harouna \& Philp 2012. Recently in 2008, exploration by China National Petroleum Corporation (CNPC) Niger Petroleum S.A has continued in the Agadem Block, which covers 27,517 $\mathrm{km}^{2}$ of the Termit basin and strikes in the NW direction, about $300 \mathrm{~km}$ long in S-N direction and 60-110km wide in W-E direction (Fig.3). Exploration targeted reservoirs in the Termit Basin are two sandstone reservoir units: (i) Eocene sandstones (Sokor1 Formation) the focus of this paper, deposited in fluvial/alluvial, deltaic and lacustrine environments; and (ii) Campanian sandstone deposited in alluvial and fluvial environments. Eocene reservoir rocks divided into 5 sand groups namely E1, E2, E3, E4 and E5 are characterized by average porosity of $25-32 \%$ and permeability of $500 \mathrm{mD}$. The second reservoir unit is less well known and has porosity of 20-25\% and permeability of up to $82 \mathrm{mD}$ (Zanguina et al. 1998, Genik 1993).

The hydrocarbons are mainly sourced from the Upper Cretaceous, Eocene marine and lacustrine shales (Genik 1993, Harouna \& Philp 2012). The Oligocene lacustrine mudstones referred to as the Sokor 2 constitute a regional seal and the most common structural styles and hydrocarbon traps are typically associated with normal fault blocks (Liu et al. 2012b, 2017, Chang \& Zung 2017). The geochemical studies of potential source rocks in the Termit Basin were conducted by Harouna \& Philp 2012 and Liu et al. 2015. Also, comprehensive oilto-oil correlation base on the biomarker and isotopic studies by L. Wan et al. 2014 distinguished two oil families in the Termit Basin. Burial history and thermal evolution of the basin was carried out by Harouna et al. 2017. 


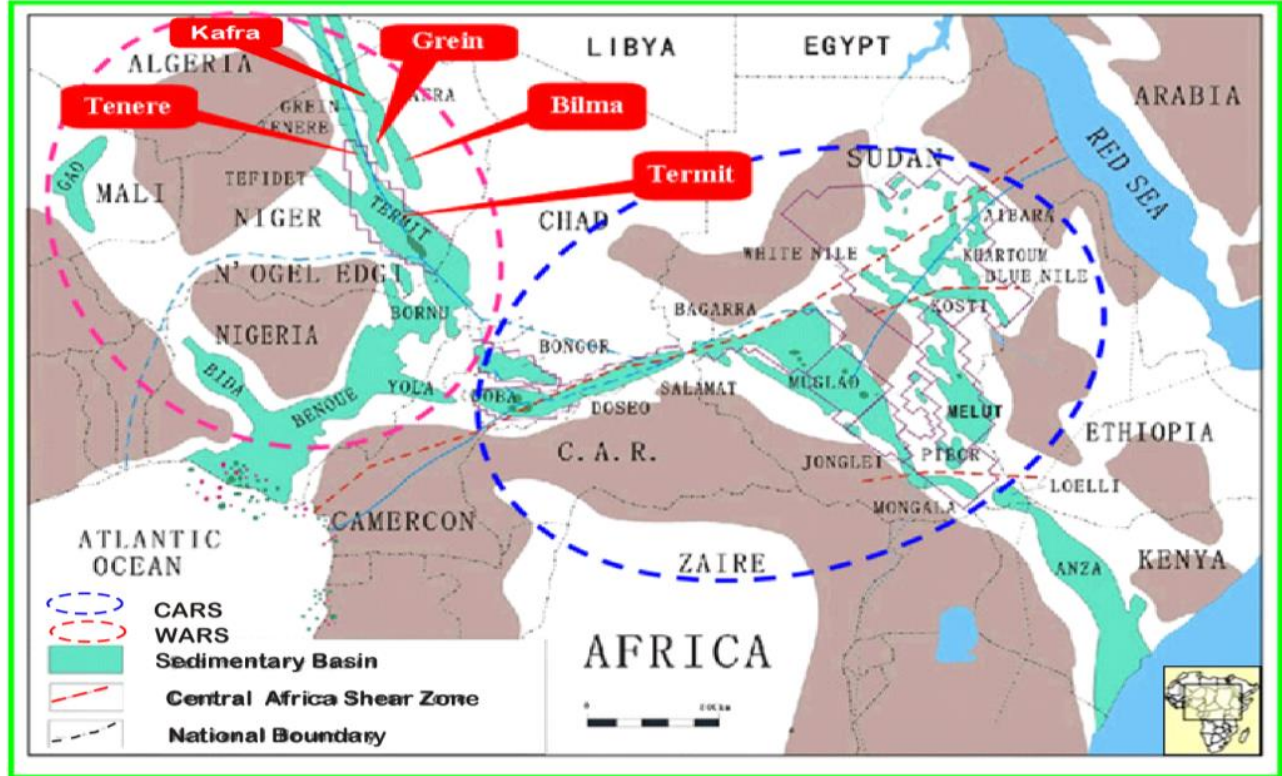

Fig. 1: Regional Geological Map Showing Location of Termit Basin within the West and Central African Rift System (Modified from Genik 1992, 1993).

However, questions remain concerning the reservoirs characterization and evaluation in the basin. For instance, structural control on reservoirs and reviews of the radioactive sand thickness and low resistivity pay intervals that will affect the hydrocarbon assessment was carried out by Chang \& Zung 2017. But it not addresses the issues of reservoirs petrophysic parameters and its diagenetic controls. Therefore, the present paper seek to further investigate diagenesis and reservoir quality evolution by describe the micro-features of the reservoir of major pay-zone in Sokor1 Formation. More especially we seek to answer the following key questions:

1) What are the diagenetic processes occurred in these fluvial/alluvial, deltaic and lacustrine deposits during burial?

2) What are the highest volumetrically important mineral cements?

3) What events control reservoir quality?

4) Has oil in place had any discernible effects on sandstone diagenesis?

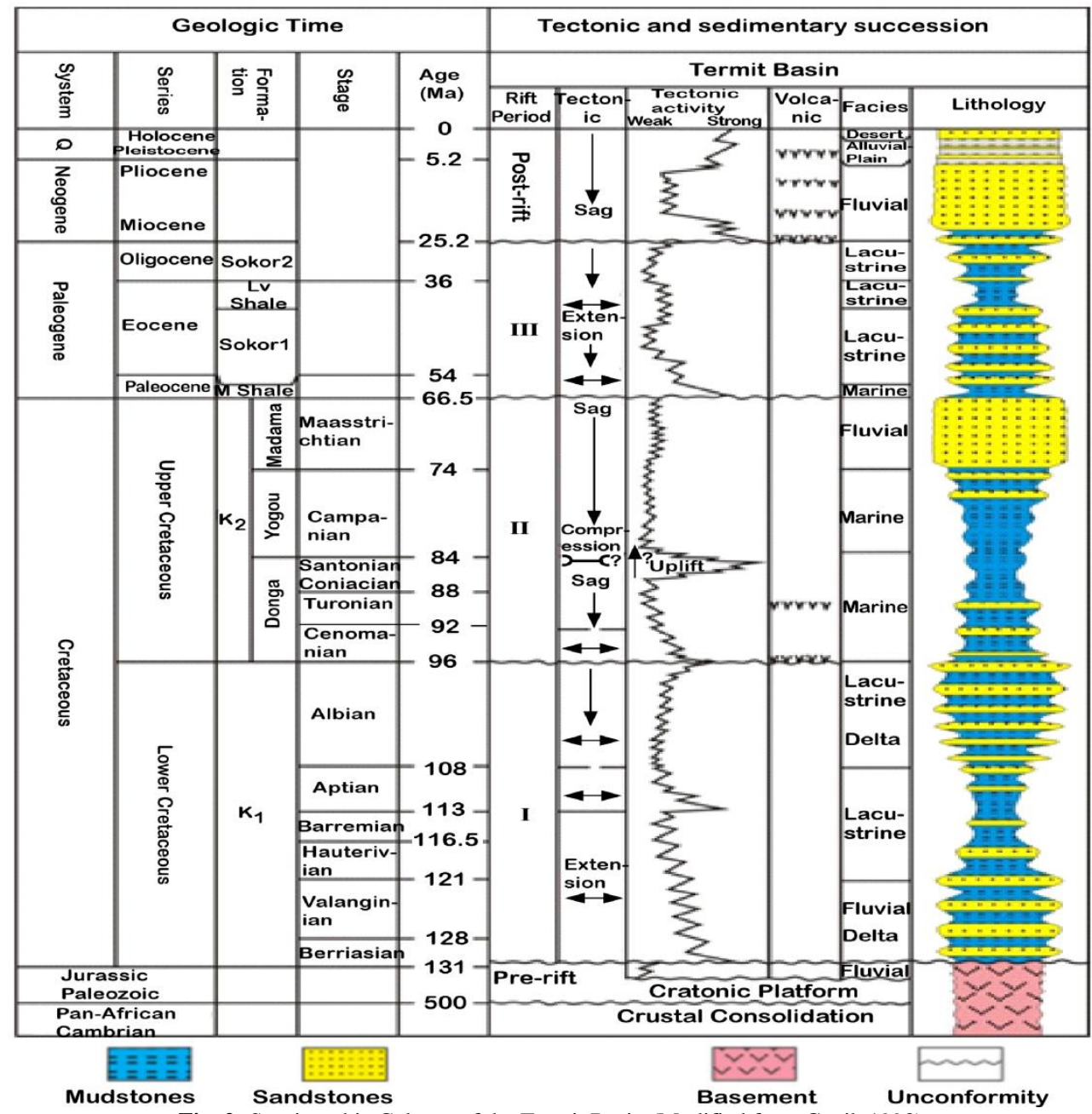

Fig. 2: Stratigraphic Column of the Termit Basin (Modified from Genik 1993). 


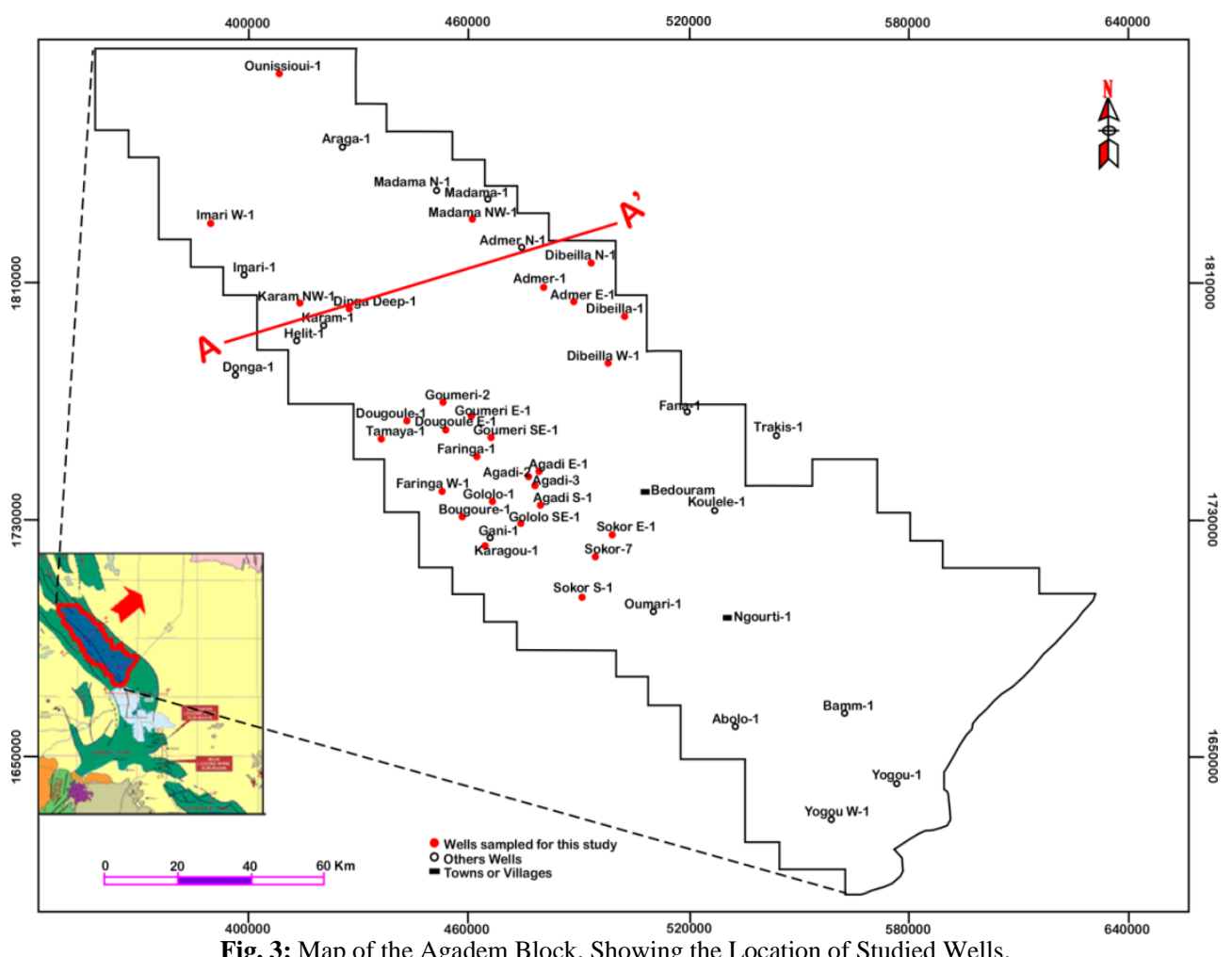

\section{Regional geologic setting and structural evolution of the basin}

The Termit Basin developed under the background of the opening of the South Atlantic Ocean in Cretaceous. From the Early Aptian to Late Albian, the African-Arabian Plate extended in NE-SW direction (Faure 1966, Louis 1970, Petters, 1978, 1981) and pre-Pan-African metamorphic zones and Pan-African fold belts moved in NW-SE direction (Maurin \& Guiraud 1993). Intracontinental rift basins in East Niger, Chad, Sudan, etc. entered their initial syn-rift period and subsided rapidly along NW-SE boundary faults, giving rise to terrestrial sandstone and mudstone of thousands of meters (Guiraud et al. 1987, 1992, Guiraud \& Maurin 1991).

In Late Cretaceous, syn-rift activities became weakened inside the African-Arabian Plate, when the global sea level reached its high in the Phanerozoic Eon and sea water came from Neo-Tethys Ocean and South Atlantic Ocean to bring on transgression on a large scale (Ziegler 1988, Genik 1992, 1993). There was a trans-Saharan Seaway inside the African Plate (Guiraud \& Maurin 1992), which separated Hoggar uplift and Tibesti uplift and traversed Benue Trough, Chad, Niger, Algeria and Mali from the south to the north. At the end of Cretaceous, sea level descended and sediments in Central and West African basins were mainly of fluvial facies. From the end of Maastrichtian to Early Paleocene, the African-Arabian Plate underwent regional uplift and was exposed to certain denudation in Upper Cretaceous (Guiraud 1993). In Paleocene and Middle Eocene, rifting activities occurred again in basins in Eastern Niger, Sudan, Kenya, etc. In Late Eocene (37 Ma), the African-Arabian Plate collided with the Eurasian Plate (Binks \& Fairhead 1992) with tectonic compression in NNW-SSE inside the plate (Schäfer et al. 1980); after that, the African-Arabian Plate entered a period with active magmatic activities and active extension mainly in NEE-SWW or near EW direction (Fairhead 1986, Daly et al. 1989, Binks \& Fairhead 1992, Genik 1992, 1993). Rift basins in NW-SE direction in Central and West Africa entered intense syn-rifting stage and severe magmatic activities appearing at such weak crustal structures as Pan-African fold belts (Maurin \& Guiraud 1993). At the beginning of Miocene ( 22 Ma), the African-Arabian Plate collided with the Eurasian Plate more violently (Ziegler 1992, Anketell 1996) and internal plate was structurally compressed, uplifted and denuded.

According to fault activity characteristics of the basin (Fig.4; Fig.5), and integrated with regional tectonic evolutionary setting, the structural evolution of Termit may be divided into three periods and six stages. Pre-rift period includes Pan-African crust fitting stage and Cambrian-Jurassic steadfast craton stage, syn-rift period includes Early Cretaceous rifting stage, Late Cretaceous Rifting-subsidence Transition Stage and Paleogene rifting stage, post-rift period includes Neogene-Quaternary depression stage.

During the Pre-rift period (770-130 Ma, Fig.2), structural evolution in Termit Basin may be dated back to Precambrian Pan-African crust fitting movement (about 770-550 Ma), during which Pan-African ancient land formed (as a part of Gondwana Land). At the same time, some areas with specially oriented weak structures came into being, which became preexisted fracture zones in Early Cretaceous to Paleogene rifts (fig.5). In Cambrian-Jurassic stage (about 550-130 Ma), Central and West Africa was covered with terrestrial sediments overlapping from the north to the south, which formed wedge shaped craton. Thermal metamorphism occurred in some local areas along weak structures in Pan-African ancient land which result of high-grade metamorphic gneiss and low-grade metamorphic strata in the Termit basins (Table 1). With the disintegration of Gondwana Land and the initiation of the Atlantic Ocean and the Indian Ocean (about $130 \mathrm{Ma}$ ), the Termit Basin entered faulting, structural subsidence and deposition in Early Cretaceous to Paleogene Period. The syn-rift period (130-96 Ma, Fig.2), at the Early Cretaceous rifting stage, the internal African-Arabian Plate was dominated by extensional stress in NE-SW direction. In Eastern Niger, intense rifting gave rise to a series of NW-SE faults following the same trend of the weak structures (pre-Pan-African metamorphic zones) in the basement (Fig.5), giving birth to a series of grabens and half-grabens groups (Fig.5; Fig.1). At that time the subsidence center of the Termit Basin lay in Dinga sag (Fig.4). At this stage, stratigraphic distribution was dominated by faulting activities at graben boundaries or half-graben boundaries and the internal is provided with three complete coarse-finecoarse cycles. Its lithological components include alternate layers of fluvial, deltaic, shore-shallow lacustrine sandstone and mudstone (Fig.2). Early Cretaceous rifting stage is bordered by top and bottom unconformable surface; the bottom surface separates pre-rifting deposition from syn-rift deposition and top surface is a transitional surface of Late Cretaceous Rifting-subsidence Transition Stage (96- 
66.5 Ma, Fig.2). At this later Cretaceous stage, the basin experienced short-term rifting at its early stage followed by long-term thermotectonic subsidence, generally dominated by depression with relatively weak faulting activities. Basin groups in East Niger are a unified marine basin against thermal precipitation and large-scale transgression, which is deposited with massive marine sandstone and argillite and is represented by Donga Formation and Yogou Formation. At its later stage of Santonian, compressional tectonic movement made the basin uplift as a whole and relative sea level dropped down gradually with an eventual transition to continental environment in Maastrichtian represented by massive braided river sandstone of Madama Formation (Fig.2). At that time the subsidence center of the Termit Basin lay in the central part of Dinga sag (Fig.4). The syn-rift period ended with the Paleogene rifting stage (66.5-25.2 Ma, Fig.2) in which, deposition occurs against the tectonic setting of large-scale extension of the African-Arabian Plate. Faulting activities were relatively weak in the period from Paleocene to middle Eocene. From end of Eocene to middle Oligocene, the basin experienced intense extensional faulting process due to the regional extensional stress in NEE-SWW direction and strike in NW-SE. The lithological components mainly include Sokor1 Formation deposits in lacustrine and delta sedimentary environment and shore-shallow lacustrine and semideep lacustrine mudstone of Sokor2 Formation (Fig.2). The subsidence center lies in the side of Dinga faulted terrace which is close to Dinga sag (Fig.4). At the end of structural evolution of the Termit Basin, sedimentary formations in post-rifting period (25.2-0Ma, Fig.2) mainly include the Neogene and Quaternary deposits, which are in angularly unconformable contact with underlying syn-rift sedimentary formations. They are mainly fluvial sediments and alluvial plain sediments (Fig.2) and lithologies mainly include sandstone and sand. The basin was generally dominated by thermal depression with weak tectonic activities. The subsidence center lay in the middle of Dinga sag (Fig.4).

Table 1: Basement and Igneous Rock Dating Data in the Termit Basin and Surrounding Basins after Genik 1993) (R: Radioactivity Dating; S: Inferred from Relevant Formations and Output Patterns)

\begin{tabular}{|c|c|c|c|c|c|c|}
\hline Basin & Well Name & Depth $(\mathrm{m})$ & Lithology & Occurrence & $\operatorname{Aga}(\mathrm{Ma})$ & Notes \\
\hline \multirow[t]{4}{*}{ Grein } & Seguedine-1 & 3143 & Biotite, gneiss, pegmatite & Bedrcok & $434-489$ & $\mathrm{R}$ \\
\hline & Gosso Lorom & Outcrop & basalt, dolerite, tuff & Eruptive rock & $<1-10$ & $\mathrm{R}$ \\
\hline & Iaguil -1 & 2486 & Homfel, schist & Bedrock & $>266-<116$ & $\mathrm{R}$ \\
\hline & Iaguil A-1 & 1250 & Alkali diabase, schist & Bedrock & $8.6 \pm 0.5$ & $\mathrm{R}$ \\
\hline \multirow[t]{4}{*}{ Termit } & Dilia Langrin-1 & 1987 & Granite & Bedrock & $190 \pm 7$ & $\mathrm{R}$ \\
\hline & Sedigi-1 & 2095 & rhyolite, basalt & rock wall & $\leq 85$ & $\mathrm{~S}$ \\
\hline & Sedigi-2 & 2103 & Rhyolite & rock wall & $\leq 85$ & $\mathrm{~S}$ \\
\hline & Kumia-1 & 4100 & Dolerite & Bedrock & $\leq 95$ & $\mathrm{~S}$ \\
\hline $\begin{array}{l}\text { N'Dgel } \\
\text { Edgi }\end{array}$ & N`Dgel Edgi-1 & 2776 & $\begin{array}{l}\text { metamorphic rock, quartz, mica, } \\
\text { schist, phyllite }\end{array}$ & matrix & Pan-African & $?$ \\
\hline
\end{tabular}

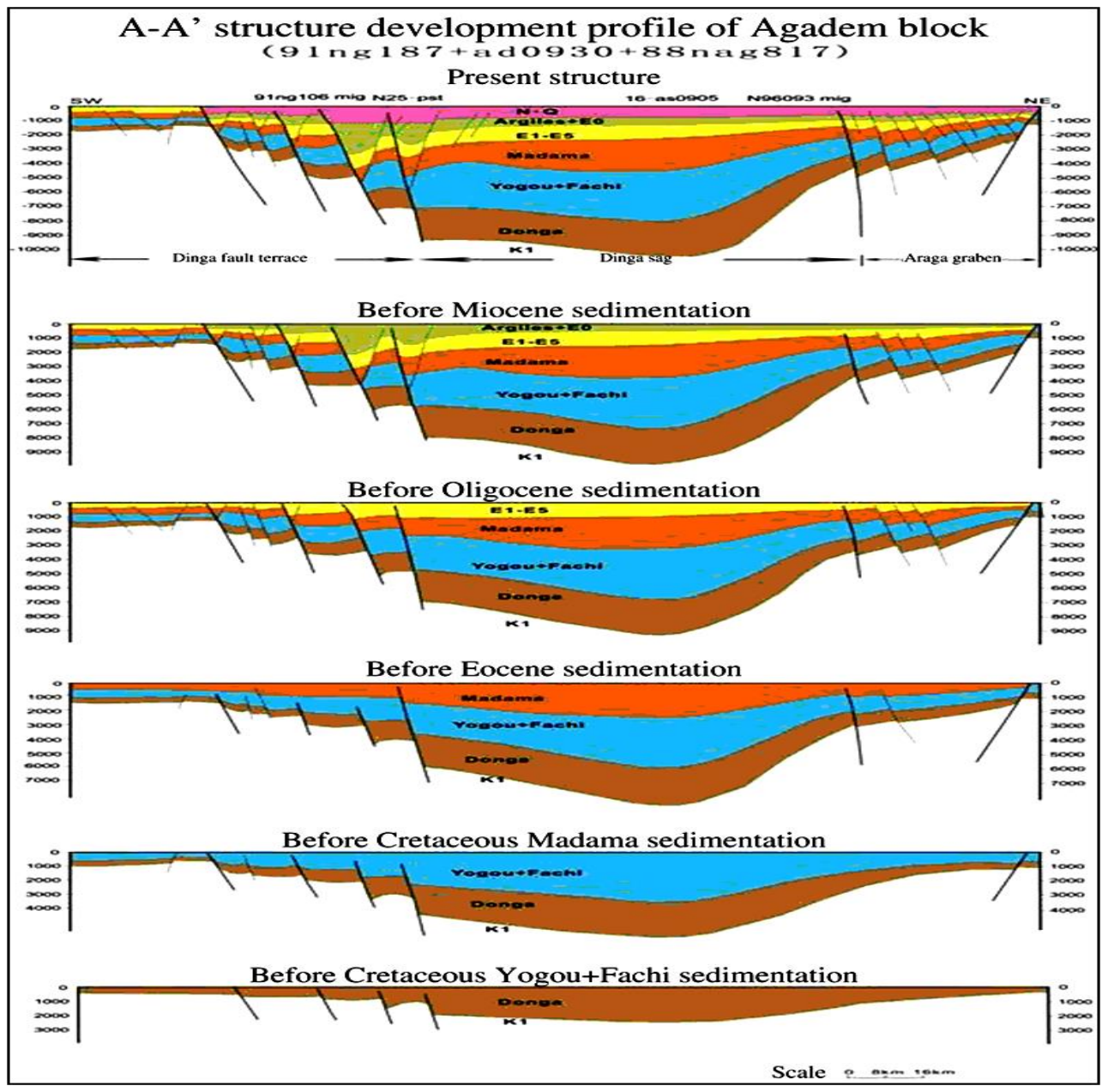

Fig. 4: Structural Evolution Section of Termit Basin, Eastern Niger. 


\section{Samples and methods}

This study included data from the analysis of side wall core (SWC) sandstones samples of 30 wells (Fig.3) of Termit Basin representing different depths, collected from Sokor1 Formation. The porosity and permeability evaluation is based on the logging data analysis, so as to look for the general rule of physical properties of each reservoir sand groups; also, the surface-pore ratio is used. The homogenization temperature data of enclosure in rock samples used were obtained from the unpublished data (CNPC Niger Petroleum S.A).

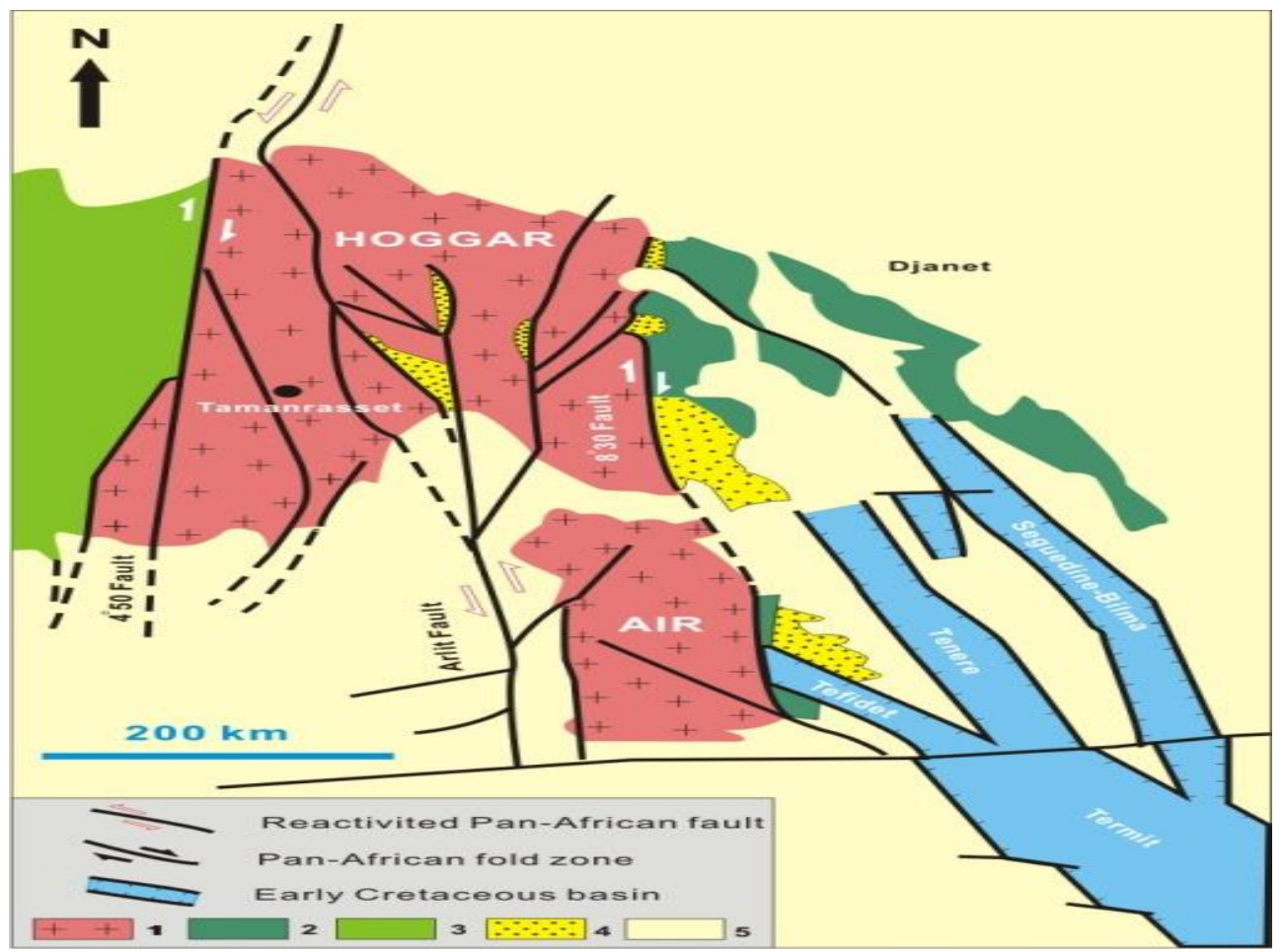

Fig. 5: Pre-Pan-African Metamorphic Zones and Basin Groups in East Niger (Modified from Maurin \& Guiraud 1993): (1: Re-Active Gneiss (>2 Ga); 2 : Pre-Pan-African Metamorphic Zones ( 730 Ma); 3: Upper Proterozoic Unit; 4: Later Proterozoic Pyroclast Schist Zone; 5: Phanerozoic Sedimentary Cover).

Analytical techniques utilized in conducting this study included thin-section petrography, scanning electron microscopy (SEM) and Xray diffractometry (XRD). Samples selected for thin-section petrographic studies were impregnated with blue or red epoxy resin to help distinguishing porosity. A total of 142 thin-sections were investigated under polarizing microscope. The quantification of diagenetic and detrital components, visual porosity, pore types, and sorting parameters, as well as textural modal on grain size, were determined using counting 300 points in each thin-section. Bulk sandstones SWC were also observed by scanning electron microscopy (SEM) at $20 \mathrm{kv}$ with a Cambridge Stereoscan 240. The later has been used to confirm the already identified clay minerals on thin-section, to determine pore structure and mode of clay occurrence within pore spaces. X-ray diffraction (XRD) of oriented mounts of bulk sandstone samples was performed after they were air dried, glycol saturated and heated at $450^{\circ} \mathrm{C}$ for $4 \mathrm{~h}$. The composition of the mineral fraction was determined by fitting the XRD pattern to the sum of the theoretical individual patterns of different contents. For the purpose of the clay minerals identification on the less than $2 \mu \mathrm{m}$ size fraction separated from bulk samples by settling in a water column, XRD was conducted following standard procedures. Prior to separation, each sample was dispersed in deionized water, disaggregated with diluted $\mathrm{H}_{2} \mathrm{O}_{2}$ and washed several times. The less than $2 \mu \mathrm{m}$ size fractions were obtained by sedimentation.

\section{Results}

\subsection{Lithologic features of reservoirs}

The Sokor1 Formation, with a present thickness of 300-900 m represent a sequence of dominantly sandstones interbedded with shale/mudstones divided from the top to the base into 5 sand groups of pay zone ranging from E1 to E5. Based on the overall lithology analysis and grain size distribution, the E1-E5 sand groups are dominated by fine to medium-grain, silty and some coarse-grained (Fig.6) and represented several representative sedimentary micro-facies, including distributary channel of delta plain, underwater distributary channel in delta front, mouth bar in delta front, distal bar in delta front and Shallow-lake bank bar. Generally, these sandstones are texturally mature. Sorting ranges from poor to moderate. The roundness of the detrital grains varies mainly from sub-angular to rounded (Fig.6F and G). The grains in the reservoir are featured by point contacts, long contacts, suture contacts and concavo-convex contacts can also be seen in some local area (Fig.6C and D).

The Paleogene Sokor1 sandstones are mostly quartz sandstone, lithic quartz-arenite and rarely lithic fedspathic-quartz-arenite with an average mass fraction of quartz $95 \%$, feldspar $1.6 \%$ and rock fragments $3.4 \%\left(\mathrm{Q}_{95} \mathrm{~F}_{1.6} \mathrm{R}_{3.4}\right)$ (Fig.7). They have a mass fraction of quartz grains $99 \%$ at most and $66 \%$ at least, and $95.8 \%$ on average of the rock volume, feldspar $4 \%$ at most and $1 \%$ on average and rock fragment $32 \%$ at most, $1 \%$ at least and $3.7 \%$ on average. The types of rock fragments are igneous, metamorphic and sedimentary rock. The E1-E5 sandstones have an average framework composition of quartz 88.48\%-82.68\%, clay mineral $11.90 \%-8.20 \%$, K-feldspar $2.97 \%$ $0.16 \%$, plagioclase $0.16 \%$ only present in E2, calcite, dolomite, siderite, pyrite, halite and barite are present in some sand groups (Fig. 8 ). The relative development of siderite suggest weak oxygen-free sedimentary environment (Lan et al. 2015). 


\subsection{Diagenetic processes}

The Sokor1 Formation in Termit Basin has undergone numerous diagenetic processes that exert a great significance to the reservoir property and influence on its quality. Through the observation of thin-sections as well as the research on SEM and XRD analysis, there are four types of diagenesis considered to be of great significance to the sandstones reservoir of Agadem Block, namely, compaction, cementation, dissolution and replacement. The compaction is mainly mechanical type, but the chemical compaction is (pressure solution) rare. The cementation mainly includes carbonate, quartz overgrowth, clay minerals and pyrite. Dissolution mainly includes feldspar grain, quartz grain and clay matrix.

\subsubsection{Compaction}

Textural features of Sokor1 sandstones shows occurrence of various degrees of mechanical compaction, depending on the extent to which the rocks have been buried. The major compaction phenomena including, (i) oriented compaction of grains, took place mainly in siltstone and sandstones with inter-grain matrix content. As burial depth increase, the formation pressure also increase, which leads to the orientation array of detrital grains (Fig.6A). (ii) Deformation of plastic grains is mainly the bending, tensioning or embedment of flexible grains through which, microfractures in brittle framework grains can occur and solid grains could be broken and crashed or even transformed into fake matrix (Fig.6B and H). (iii) Rearrangement and contact relations of detrital grains changed with burial depth increase. The contact of grains became close and turned into concavo-convex and linear contact from point contact (Fig.6C and D). These phenomena imply extensive mechanical compaction in the Sokor1 Formation, specifically in the silt to fine grained sandstones that often have higher contents of pseudo-matrix than medium to coarse grained sandstones. As the inter-grains pores loss from mechanical compaction is irreversible, it is a damage-type diagenesis influencing the poorer physical property of sandstone with the increase of burial depth. Chemical compaction occurred locally due to intergranular pressure dissolution of quartz grains as indicated by the presence of straight and sutured contacts (Fig.6C).

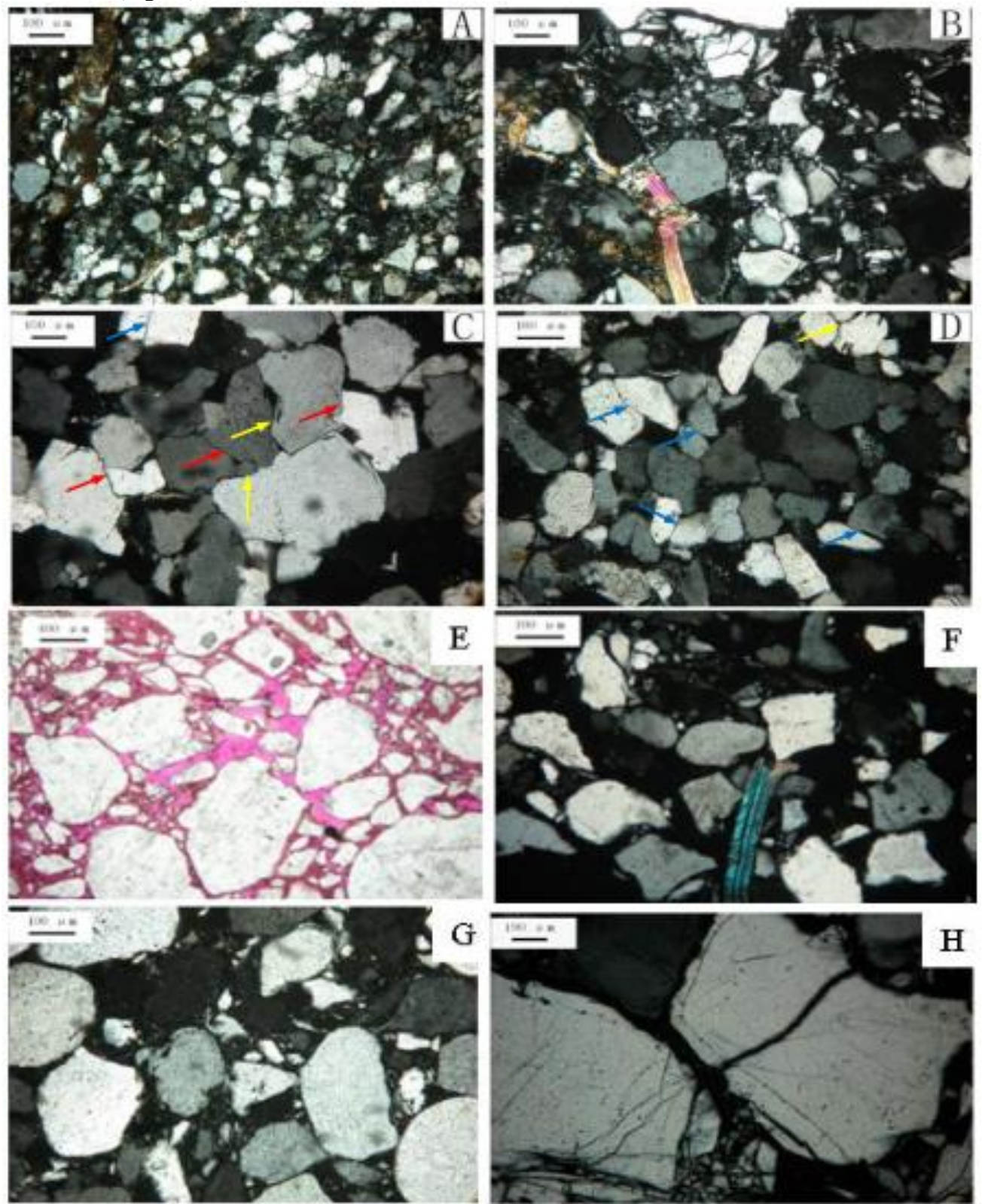

Fig.6. Thin-section photomicrographs of Sokor1 sandstones depicting: (A) Silty quartz grains, oriented compaction, Agadi-3, 2006m, E2; (B) Fine-grain quartz, compaction effects (bending, tensioning or embedment of flexible grains, brittle framework and fake matrix), Agadi E-1, 1867m, E1; (C) Medium quartz grains, well compacted with suture contacts (red arrows) and concavo-convex contacts (yellow arrows), Gololo SE-1, 2205.5m, E2; (D) Fine quartz grains, well compacted with long contacts (blue arrows), Admer-1, 1737m, E4, 
(E) Medium quartz grains, point contact, porous cementation, Dibeilla N-1, 1723m, E5; (F) Fine quartz grains, sub-angular-sub-rounded, point contacts, Dibeilla-1, 1632m, E4, (G) Medium quartz grains, sub-rounded-rounded, point contacts, Ounissoui-1, 1140m, E3; (H) Coarse quartz grains, microfractures, Goumeri-2, 2622.8m, E3

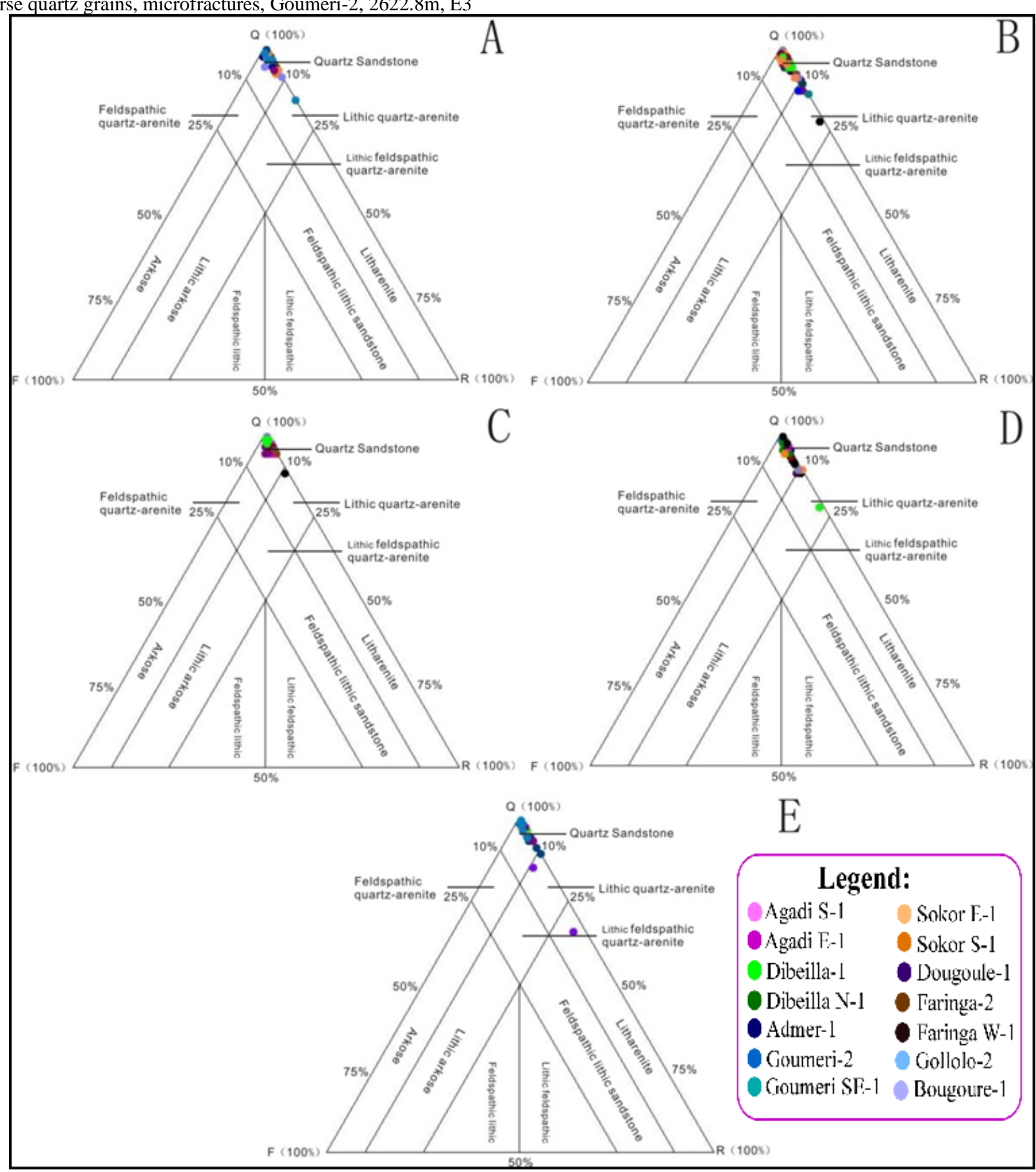

Fig.7. Triangular ternary diagrams showing the framework grain composition of Sokor1 sandstones in the study area 


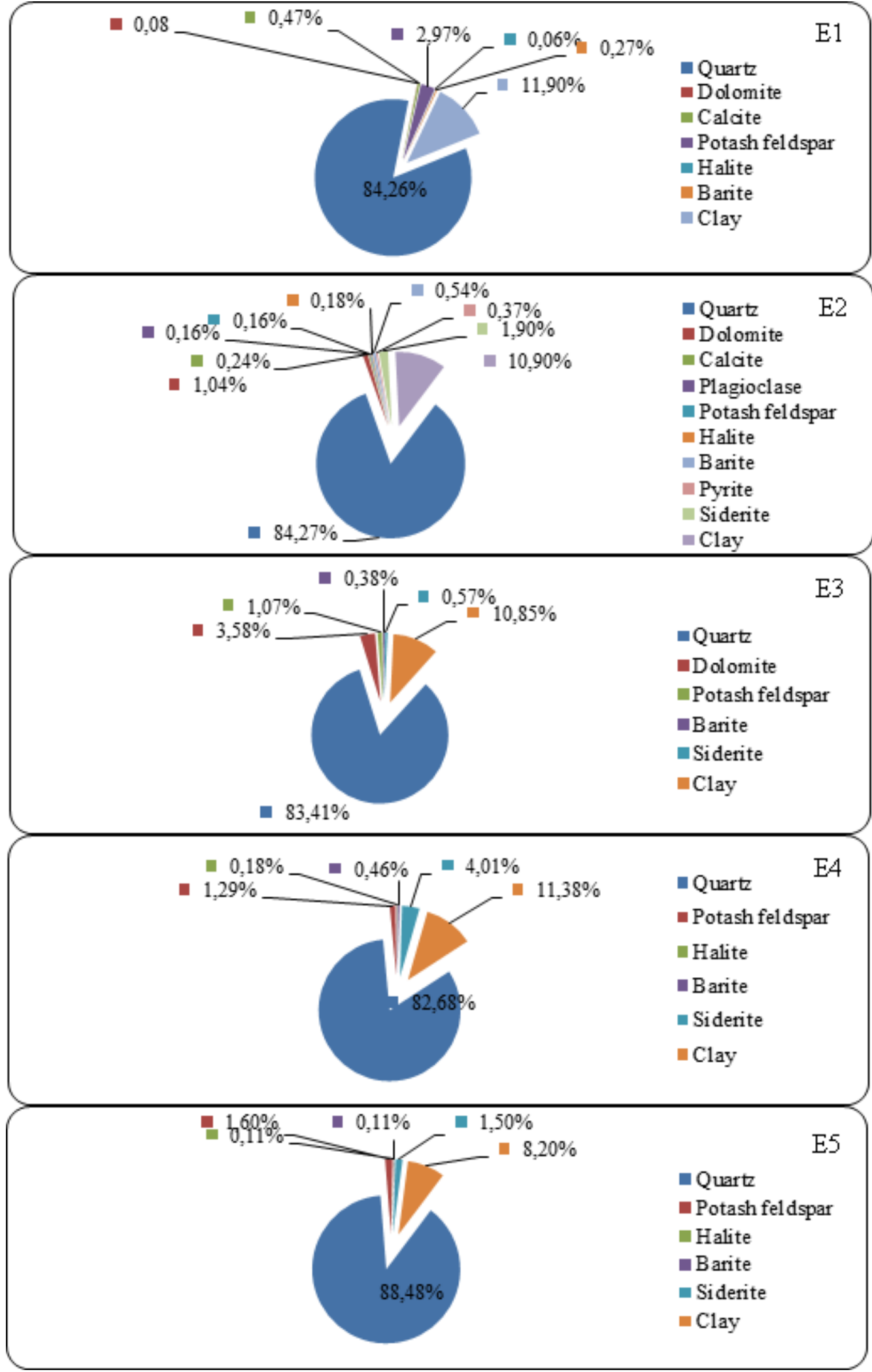

Fig.8. XRD mineral composition charts of Sokor1 sandstones in each sand groups, Termit Basin, Eastern Niger

\subsubsection{Cementation}

\subsubsection{Carbonate cement}

Carbonate cements in the Sokor1 sandstones included calcite, dolomite and siderite (Fig.8). The E1 and E2 sand groups have an average calcite content of $0.47 \%$ and $0.24 \%$ respectively which did not last long with the increase of burial depth. Calcite cements appeared sparsely as pore occluding cements which occurred as poikilitopic and patchy calcite, where inter-granular pore spaces are completely blocked (Fig.9). Dolomite occurrence increase from E1 to E3 with an average content of $0.08 \%, 1.04 \%$ and $3.58 \%$ respectively. An average siderite content of $1.90 \%, 0.57 \%, 4.01 \%$ and $1.50 \%$ occurred in E2, E3, E4 and E5 respectively (Fig.8). The present of siderite as the only type of carbonate cement in E4 and E5 may be used as indicator of dissolution or replacement of early carbonate cements as burial depth increase and increase of temperature with high Fe and low Ca contents (Abouessa \& Morad 2009). 


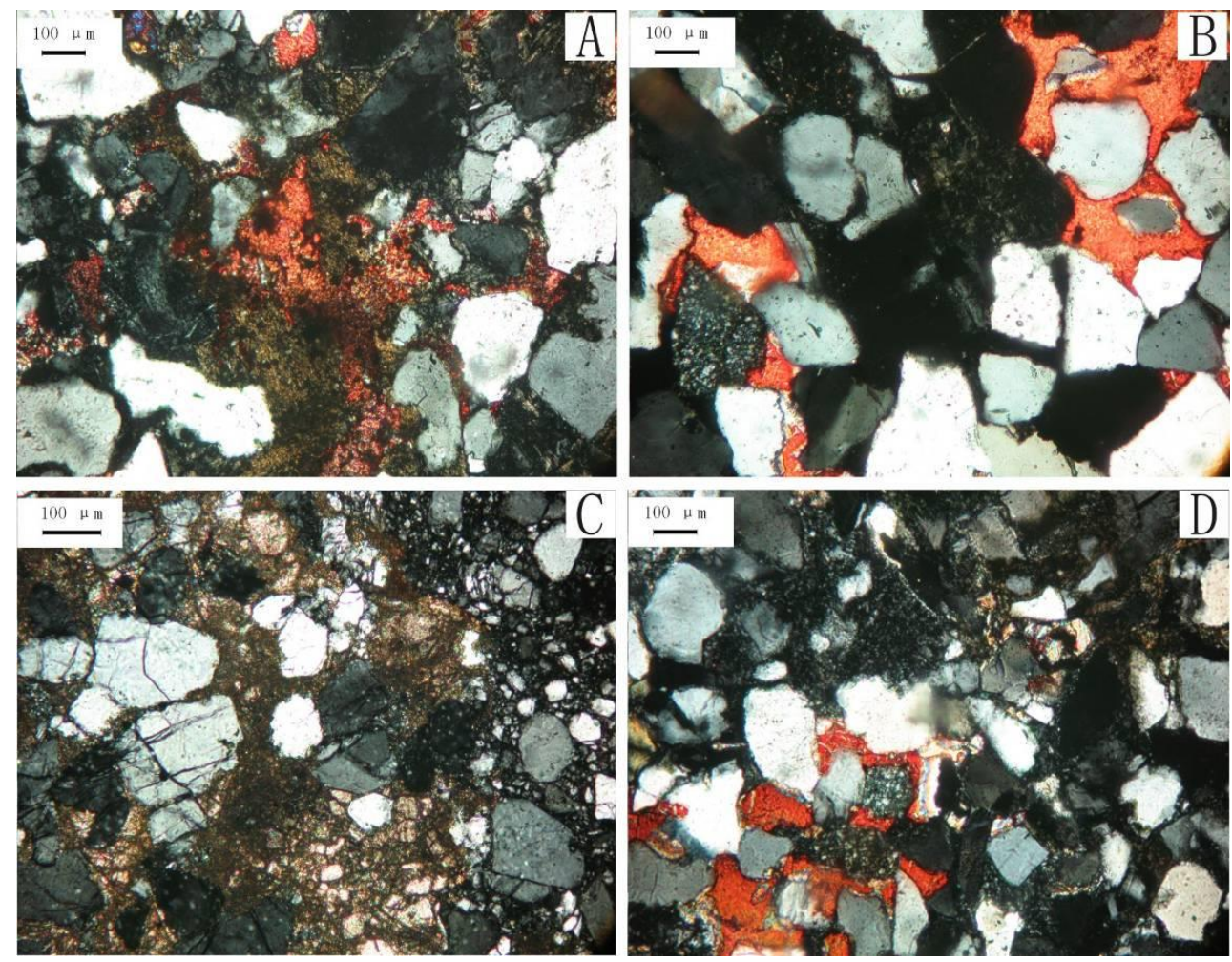

Fig.9. Thin-section photomicrographs of Sokor1 sandstones showing carbonate cements: (A) Patchy calcite reducing pore spaces, Agadi3, 2008.7m, E2; (B) Poikilitopic pore occluding calcite blocking pore throats, Dibeilla-1, 1315m, E2; (C) Patchy calcite reducing pore spaces, Goumeri E-1, 2207m, E2; (D) Poikilitopic pore occluding calcite blocking pore throats, Karam NW-1, 1730m, E2

\subsubsection{Silica cement}

Siliceous cements are common in the reservoir of the study area, which showed up in the form of quartz overgrowth and crystallite (Fig.10 and Fig.11). The mass fraction of quartz cement ranges from 0.5 to 5\%, with an average of 1.5\% and the width of overg rowth quartz side is less than $10 \mu \mathrm{m}$. In the sandstone samples with high content of matrix, the quartz cementation did not develop. Thus, the presence of quartz overgrowths is controlled by detrital quartz grains and large inter-granular pores. Quartz overgrowths occur along the detrital quartz grain edge, showing the same optical property of the quartz grains. Some authigenic quartz contains local euhedral terminations, or is inter-grown with a clay phase (Fig.11). Under the slice observation, an overgrowth side could be seen when the boundaries between detrital quartz and quartz overgrowths are made by clay coatings at the margin of quartz grains (Fig.10). The quartz overgrowth in the Sokor1 sandstones is at the Level I-II. Quartz overgrowth of first stage is overlain by quartz overgrowth of the second growth stage. The overgrowth features that characterize quartz may be changed with the increase of the depth as the secondary overgrowth of quartz strengthened.

\subsubsection{Clay minerals}

Clay minerals identified in the Sokor1 sandstones included kaolinite, chlorite, illite, mixed-layer illite/smectite (I/S) which, occurs as intra-pores cement. The content and type of clay minerals evolve with burial depth changes. As determined by XRD analysis, kaolinite is the most common clay mineral followed by chlorite in the Sokor1 sandstones (Fig.12).

1) Kaolinite:

The average content of kaolinite is $69.51 \%, 77.21 \%, 83.88 \%, 72.56 \%$, and $79.96 \%$ in E1-E5 sand groups respectively and averaging $76.62 \%$ of the clay volume in whole Sokor1 sandstones (Fig.12). In the slice, it accounts for 3\% to 5\%, up to $10 \%$ in some samples and distributed as points (Fig.13F) or thin to thicker platelets (Fig.13G and H). Under SEM, monocrystalline kaolinite is usually seen as hexagonal tablet. When polymerized, its regularity shows vermicular aggregates, rarely booklets texture and columnar (Fig.13 A-E). The single crystal of kaolinite is up to $3 \sim 15 \mu \mathrm{m}$ in size. Kaolinites occur as pore-filling and grain coatings (Fig.13C) or replacement of feldspar (Fig.13 E). Although pores filled by kaolinite are not completely occluded, they are many relic pores and micropores between kaolinite crystals (Fig.13 A) and dissolved pores. The residual pores between crystals have influence more greatly on porosity than permeability. Meanwhile, due to the existence of kaolinite fillings, the compaction is impeded, which is favorable for the preservation of the primary inter-grain pores. During the period of dissolution or weathering, kaolinite was generated by the reaction between the water, which dilutes the acidity and feldspar or other aluminosilicates or from the transformation of montmorillonite. With the burial depth and temperature increases, kaolinite will transform into congeneric minerals with high degree of structural order (Fig.16). 

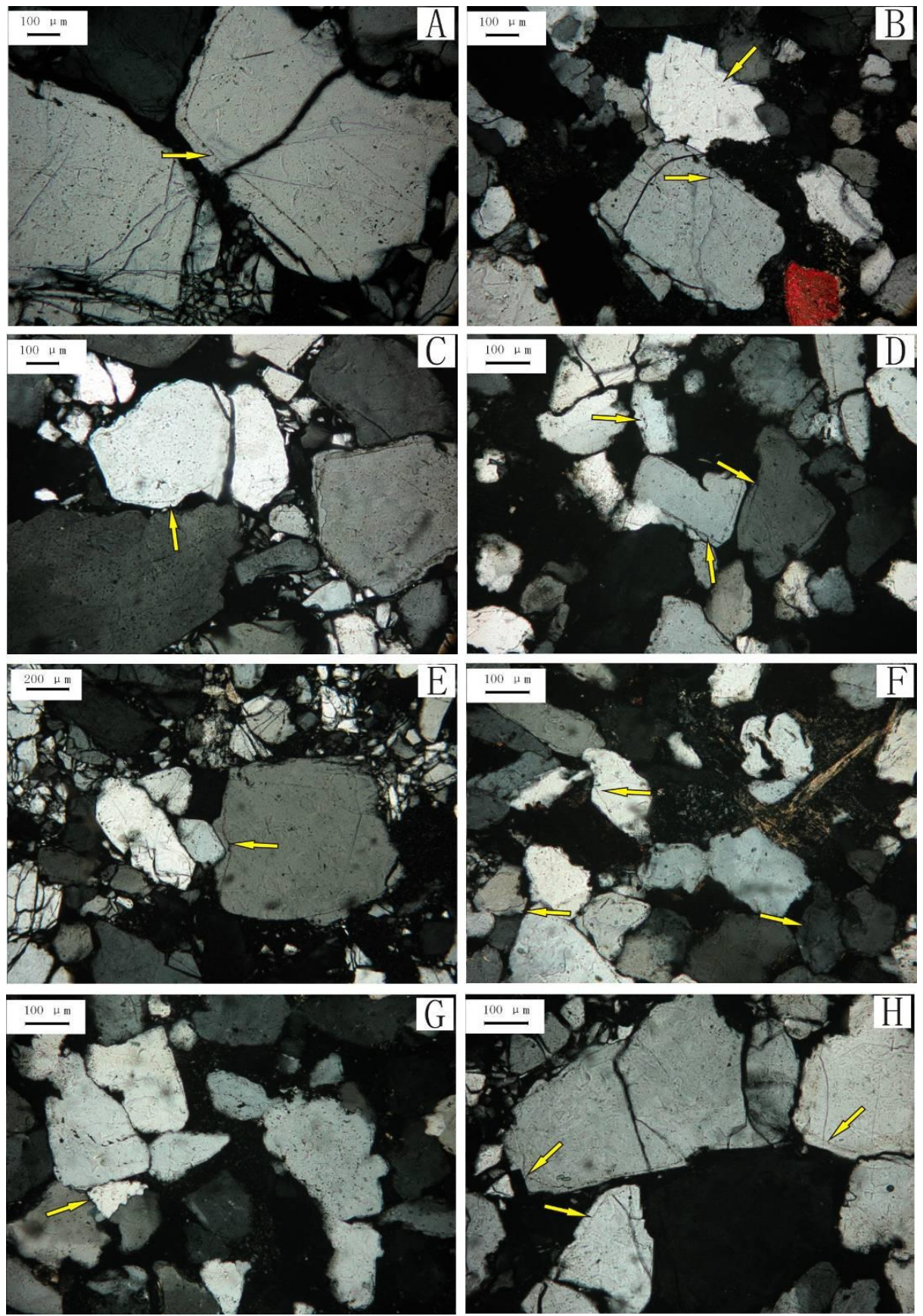

Fig.10. Thin-section photomicrographs of Sokor1 sandstones depicting silica cement in the form of quartz overgrowths (arrows): (A) Coarse-grained quartz with brittle framework, Goumeri-2, 2622.8m, E2; (B) Anisomerous quartz grains, Goumeri-3, 2533m, E2; (C) Anisomerous quartz grains, Sokor S-1, 1909m, E2; (D) Medium-grained quartz, Agadi E-1, 2203m, E4; (E) Anisomerous quartz grains with brittle framework, Goumeri E-1, 2443m, E3; (F) Medium-grained quartz, Dinga Deep-1, 2717m, E3; (G) Medium-grained quartz, Dinga Deep-1, 2885m, E4; (H) Anisomerous quartz grains, Gololo SE-1, 2431.5m, E3

\section{2) Chlorite:}

In the whole Sokor1 sandstones, chlorite account an average of $15.89 \%$ of clay minerals content and averaging $24.00 \%$, $13.30 \%$, $12.00 \%, 19.25 \%$ and $10.91 \%$ in E1-E5 sand groups respectively (Fig.12). The occurrence could be seen as chlorite coatings and pore fillings (Fig.14). The chlorite of grain-coat mainly grows at both, on the surface and along the contact surface of the grain in the form of film or rim (Fig.14C, E and F). Some chlorite crystals are oriented perpendicular to grain surfaces. Chlorite coatings in some cases covered partly or wholly detrital grains (Fig. 14E). Chlorite of pore-filling appears as rosettes or crystal aggregates growing towards the center of pores (Fig.14 A, B and D). Well-developed crystals of chlorite are nearly like hexagonal flake structure and are covered or partially engulfed by quartz overgrowths (Fig.14A and B). This later event shows that chlorite grows before the secondary overgrowth of quartz. Thus, the development of chlorite grain-coating seems to preserve some primary inter-grain pores by preventing quartz secondary growth in the Sokor1 sandstones. But instead of its contribution to the improvement of reservoir quality, its growth damages the reservoir.

3) Illite:

Illite is the mineral clay most commonly seen in the reservoir, which is formed at the later stage. It account for $4 \%$ of the clay mineral of Sokor1 sandstones. With the depth increase, illite content tends to increase from E1 to E5 except in E3, which content 2.62\% (Fig.12). The illite in the study area is displayed mainly as the fillings in the pore and sometimes as the film-like pore coatings. It demonstrates mat-like, fibrous or lath-like crystals morphology that covers the framework-grains (Fig.15A-D). The illite of mat-like filling in the pores separates the inter-grain pores into some small pores (Fig.15B). It not only occupies the space, but also reduces the permeability of the 
Sokor1 sandstones by blocking the pore throats. In the study area, the feldspar dissolution is common, which could provide sufficient materials for the forming of illite. At the same time, the crystallization of clay minerals such as kaolinite illitization is also one important reason for the forming illite as it is associated with kaolinite (Fig.15D).
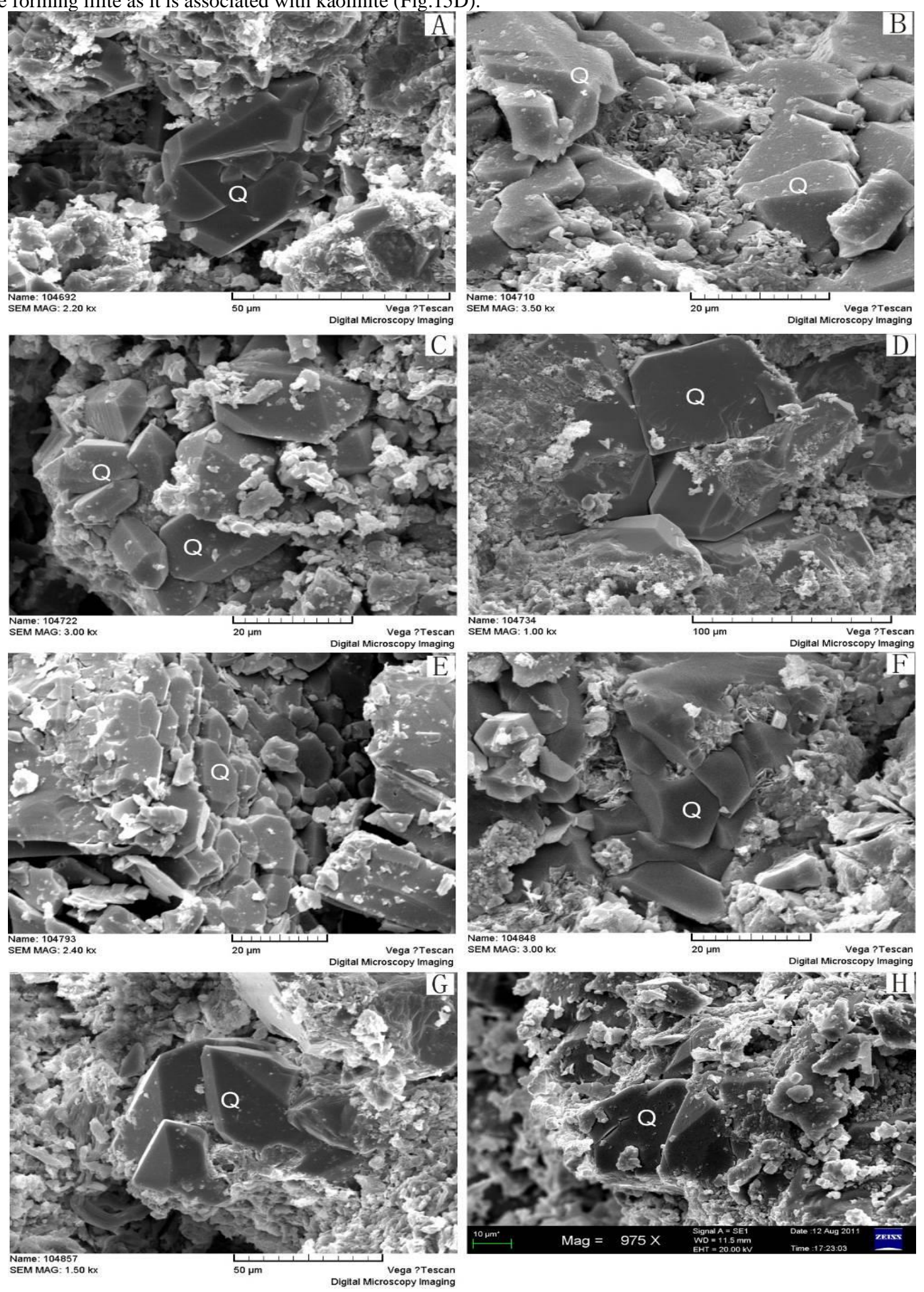

Fig.11. SEM images of quartz overgrowths consisting of euhedral crystals locally developed in primary pores. (A) Admer-1, 1857.5m, E5; (B) Sokor E-1, 1702.9m, E2, ( note pore-lining chlorite developed in inter-granular pore and coated detrital grains); (C) Agadi-3, 1986.5m, E2; (D) Goumeri SE-1, 1963.5m, E2; (E) Goumeri-3, 3127m, E5; (F) Goumeri-2, 2738.2m, E3; (G) Agadi S-1, 2057m, E2; (H) Faringa W-1, 1933m, E2

4) Mixed-layer illite/smectite (I/S):

Its occurrence in Sokor1 sandstone shows pore-lining rims and pore-filling cements, and as replacement of mud-matrix and detrital feldspar (Fig.15E-H). Mixed-layer I/S are forming typical type of flocculated structure and have a honeycomb-like texture (Fig.15G and H). As determined by XRD analysis, mixed-layer I/S account 3.77\%, 5.20\%, 1.50\%, 3.53\%, and 3.22\% of clay minerals in E1-E5 sand groups respectively (Fig.12). In the reservoir of the study area detrital smectite were not identified. Thus, mixed-layer illite/smectite was interpreted to be formed by the gradual transformation of detrital smectite from bioturbation, matrix or pseudo-matrix formed by the compaction of mud intraclasts as the process of diagenesis increasing with the increasing of burial depth. According to Zhang 2004 , this demonstrates that the Sokor1 sandstones have gone into stage A of meso-diagenesis. 

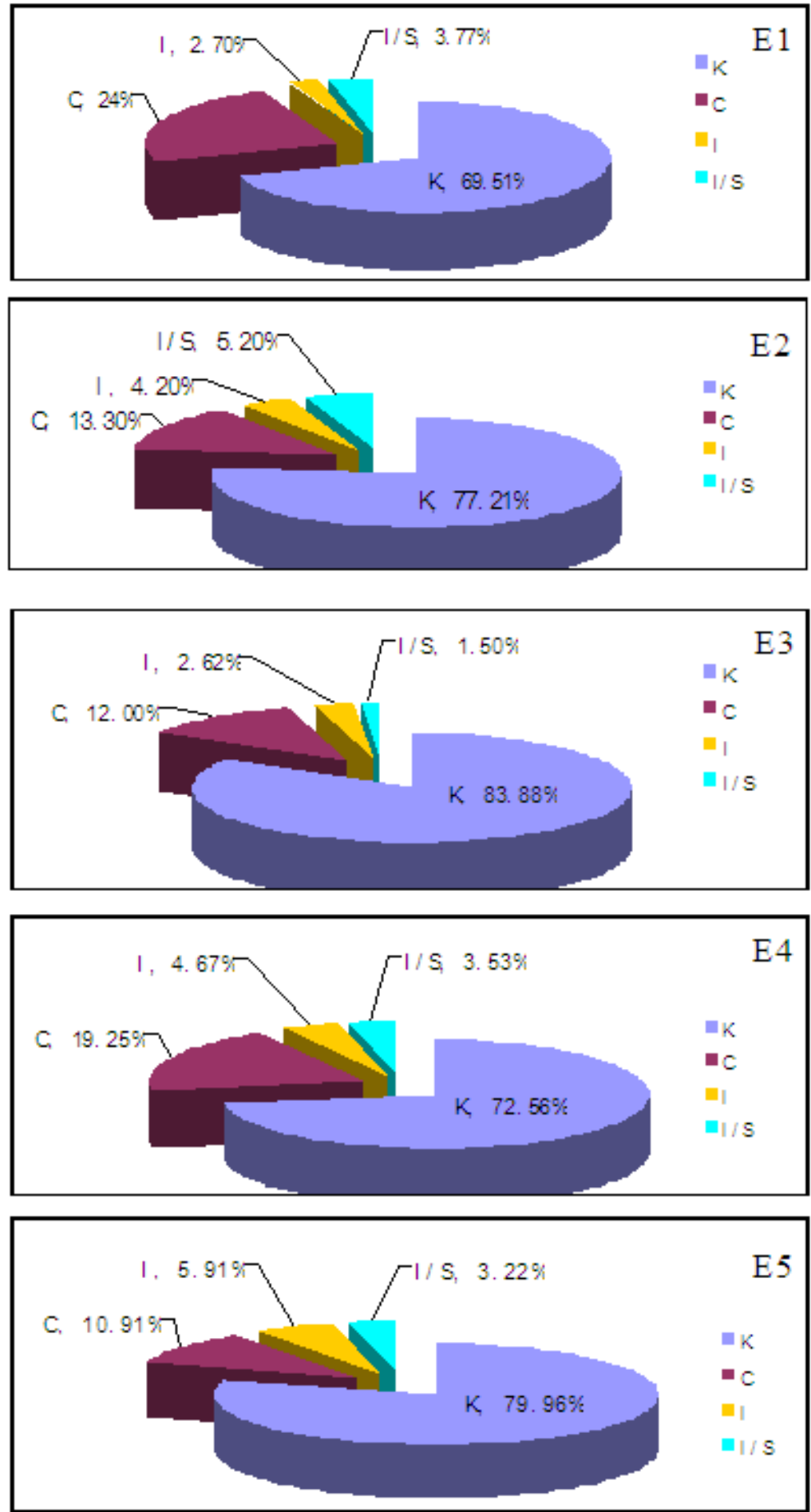

Fig.12. XRD charts content of Clay Minerals in Sokor1 sand groups, Termit Basin $(\mathrm{K}=$ kaolinite, $\mathrm{C}=$ chlorite, $\mathrm{I}=\mathrm{illite}, \mathrm{I} / \mathrm{S}=$ illlite/smectite)

5) Change of clay minerals with the depth:

The kaolinite contents decrease with the increase of depth and the content of chlorite, illite, as well as the mixed-layer I/S increases with depth (Fig.16). The existence of the mixed-layer I/S indicates the transformation effect of the clay minerals. Within the depth of 2000 to $2500 \mathrm{~m}$, the kaolinite content decreases greatly and the content of chlorite, illite as well as the mixed-layer illite/smectite increases which shown evidence of the transformation belt of clay minerals in Sokor1 sandstones. Therefore, it is predicted that the change of the pore water chemistry and alkaline medium led to the inter-transformation of clay minerals (Salman et al. 2002), thus enabling the development of the chlorite and illite and the reducing of kaolinite and smectite content (Fig.16).

\subsubsection{Pyrite cement}

Pyrite acts as a porosity reducing cement and its content is low in the reservoir of the study area. It accounts $0.37 \%$ in E2 sand group (Fig. 8). Under SEM, the occurrence of pyrite is mainly alternation or pore-filling. It displays octahedral structure (Fig.17D), and when polymerized together, it acts as pellet shown framboidal shape (Fig.17A, B and C). Pyrite crystals with intermediate textures between framboid and euhedral textures have also been observed in the studied samples (Fig.17B). This transformation of spherical pyrite microcrystals to octahedral crystals is believed to be the effect of early diagenesis. The latter statement is supported by the presence of second- 
ary growth of quartz, which engulfed or partially covers the pyrite (Fig.17C). Also, the presence of framboidal texture suggests that pyrite is generated under the oxygen-free environment (Álvarez-Iglesias \& Rubio 2012, Sawlowcz 1993).
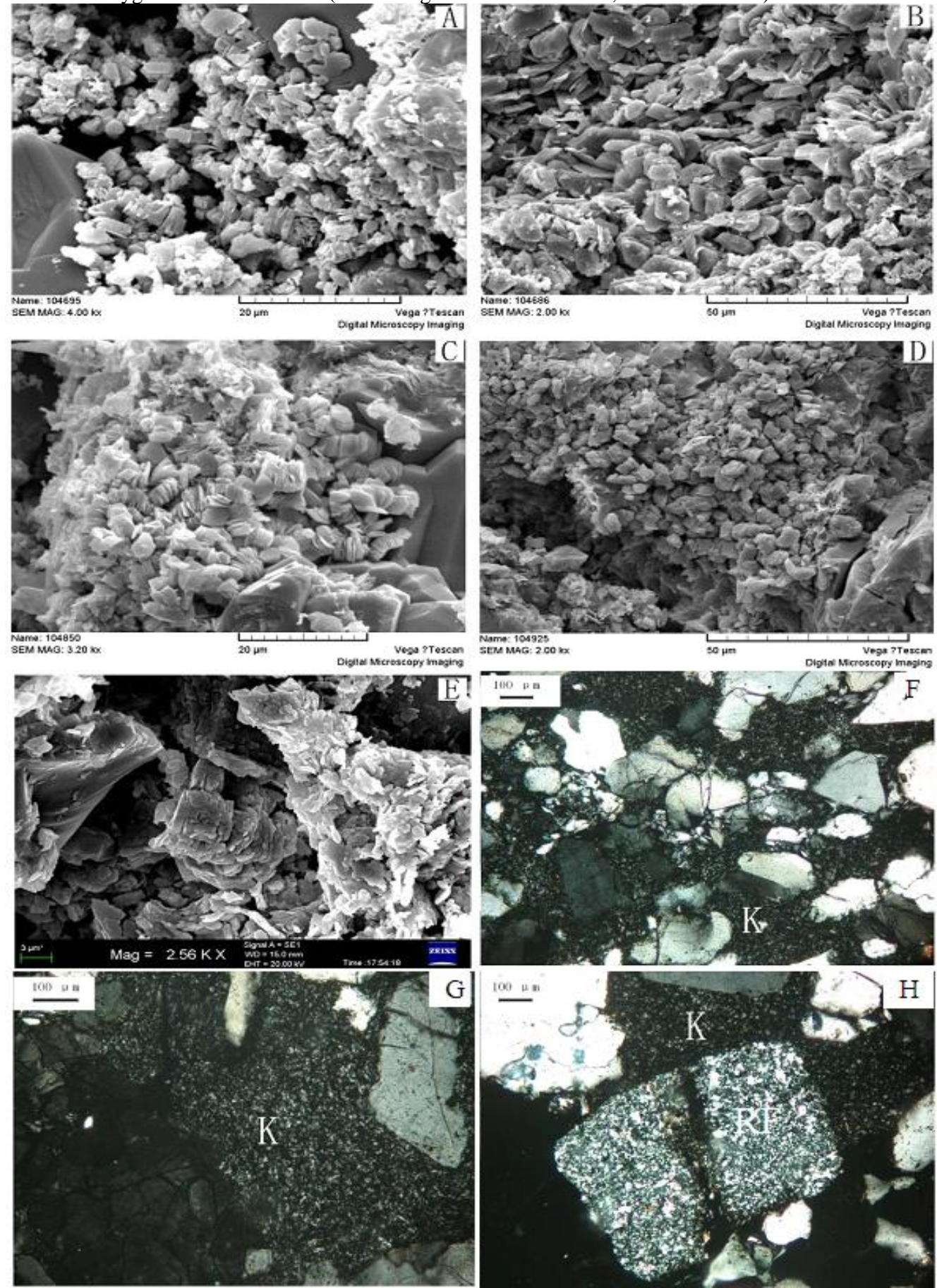

Fig.13. Scanning electron and thin-section micrographs showing character of kaolinite: (A) Vermicular kaolinite polymer filling in pores and relic pores and micropores between kaolinite crystals, Admer-1, 1857.5m, E5; (B) Vermicular kaolinite polymer filling in pores and relic pores and micropores between kaolinite crystals, Gololo-2, 2274m, E2; (C) Intergranular pore occluding clusters of kaolinite as books form, Goumeri-2, 2057m, E1; (D) Columnar kaolinite texture with micropores between aggregates, Agadi E-1, 2505m, E5; (E) Kaolinite occurring as replacement of feldspar due to dissolution of the latter, Gololo-2, 2168m, E2; (F) Grain-coating kaolinite distributed as points, Goumeri-3, 2570m, E2; (G) Thick kaolinite platelets blocking intergrannular pore, Dougoule NE-1, 2208m, E4; (H) Thin kaolinite platelets blocking intergrannular pore, Tamaya-1, 1384.5m, E4; Key: RF= rock fragments, K= kaolinite

\subsubsection{Dissolution}

Dissolution involves generally the removal in solution of part or all of previously existing minerals, which leave pores in the rocks (Boggs 2009). The dissolution is common in the reservoir of the study area. Based on the observations on the thin sections and SEM, dissolution in Sokor1 sandstones primarily exhibited as dissolution of the feldspar grains, quartz grains, and clay matrix and sometimes of mica (Fig.18 and Fig.19). In the cast slice samples of the study area, the oversized pores were probably formed chiefly by the complete dissolution of feldspar grains or rock fragments as shown in figure $19 \mathrm{C}, \mathrm{G}$ and $\mathrm{J}$. This can be also supported by the fact that the content of feldspar and volcanic debris in the area is very low (Fig.8). The dissolved feldspar usually has the port-like edge (Fig.19A, C and J). Strongly dissolved mica could take on remains, forming intra-grain pores (Fig.19E and F). Under SEM, feldspar is usually dissolved along the cleavage into the cancellate, fenester or remains, forming cast pores, hull pores or rib-like pores acting as secondary intra-pores 
(Fig.18A, C and D). The dissolution of quartz usually formed intra-pores (Fig.19D, F, G, H, I and Fig.18B). The dissolution of clay minerals usually formed inter-pores or mixed pores (Fig.19B).
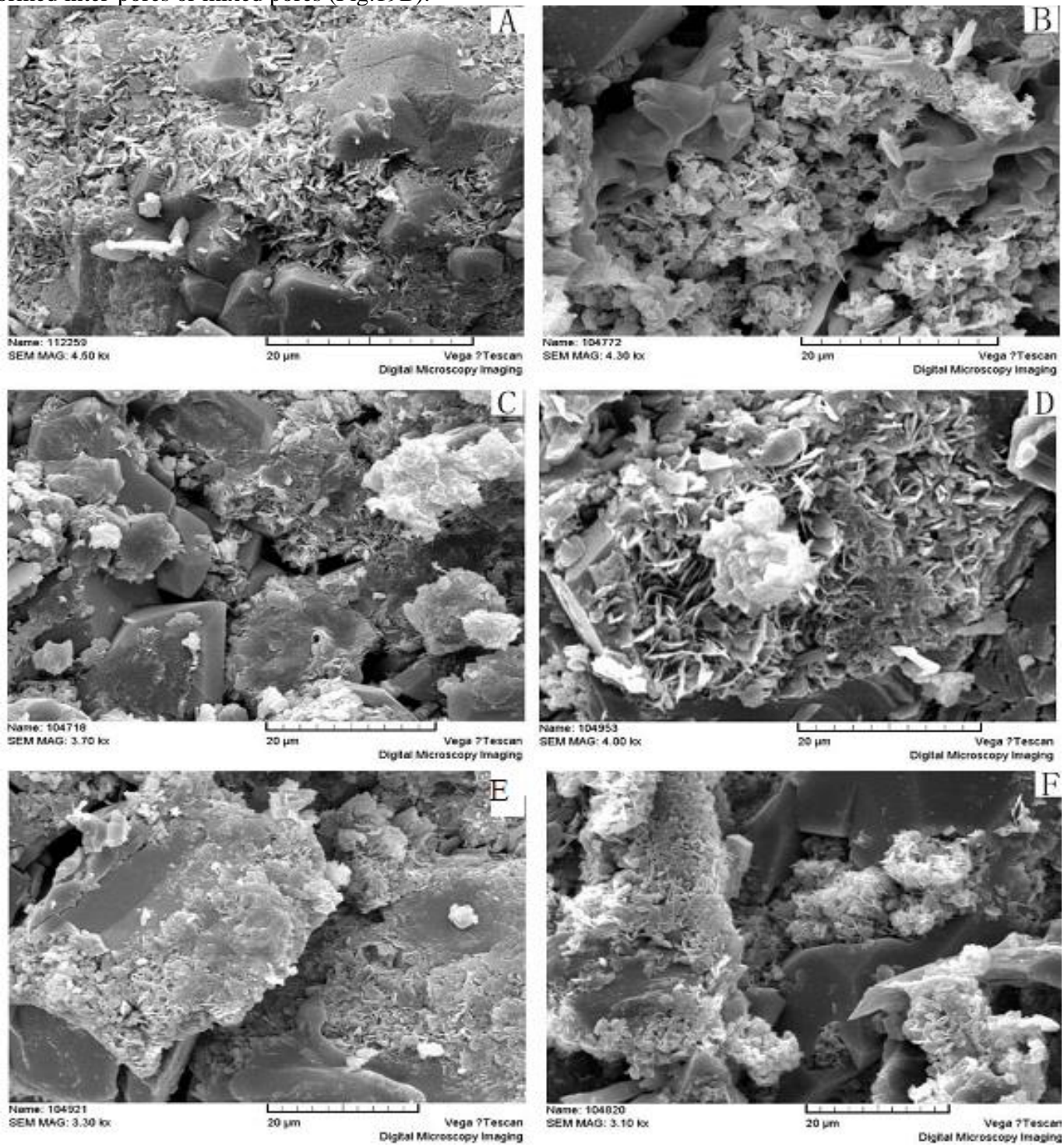

Fig.14. Scanning electron micrographs showing character of chlorite: (A) Rosette type chlorite overgrown by authigenic quartz, Agadi-2, 2009.8m, E2; (B) pore-lining chlorite developed in intergranular pore and coated detrital grain intergranular pore, Gololo-1, 2637m, E4; (C) Chlorite rims partially engulfed by quartz overgrowths, Agadi-3, 2022m, E1; (D) Rosette like chlorite filling in pores, Dinga Deep1, 2855m, E4; (E) Chlorite rims covering detrital grains and film of rim coating grains, Bougoure-1, 1991m, E4; (F) Pore lining chlorite fringes are developed in intergranular networks, Gololo SE-1, 2683m, E4

\subsubsection{Replacement}

Replacement refers to the simultaneous dissolution and precipitation, which is one mineral replace by another under the condition of maintenance of alternated mineral crystal or agglomerate. It is common in the study area (Fig.20). Usually, it is related to the foreign materials such as $\mathrm{CO}_{2}$, increase in $\mathrm{pH}$ and change of water $\mathrm{Eh}$ in the pore, increase of pressure and temperature during the late stage of early to middle diagenesis (Walker 1962, Fairbridge 1967, Lakshtanov \& Stipp 2010). In Sokor1 sandstones reservoirs, there are mainly the following kinds of replacement: (1) Carbonate cements (calcite) alternate the quartz grains and inter-grain matrix is common (Fig. 20 A, B and C). In thin section, it is commonly seen that the edge of quartz grain is port-like shape and becomes irregular remains-like edge due to the alternation of calcite. Quartz grain alternation is even most or entire alternated by calcite. (2) Clay minerals alternate debris which occurs in sandstones rich in clay matrix, in particular chlorite alternate others due to dehydration caused by the gradual compaction in the basin (Fig.20D). This phenomenon can damage porosity to some extent (Fig.20 A and D) and also contributed into the formation of micropores (Fig.20B and C). 

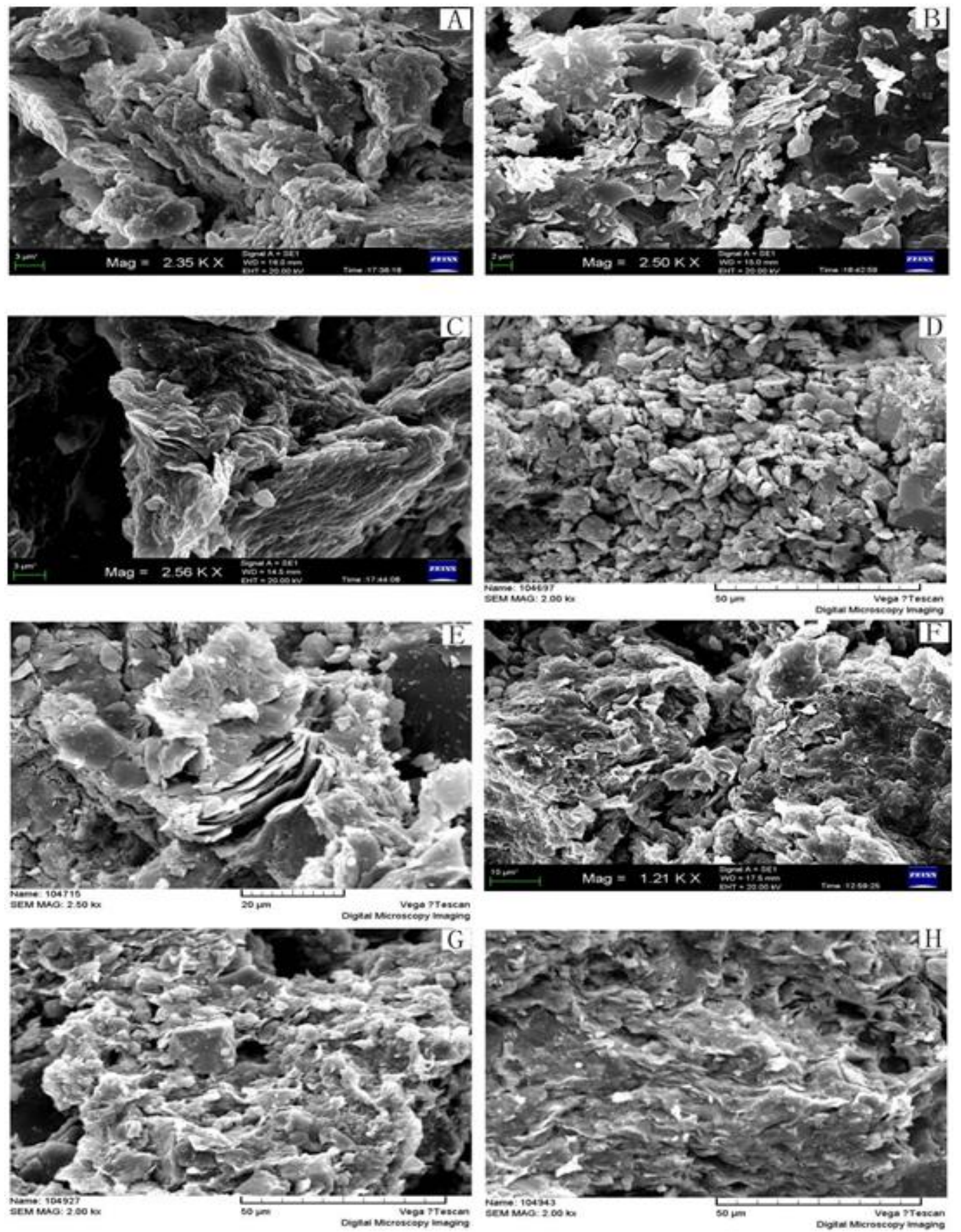

Fig.15. Scanning electron micrographs showing character of illite and mixed-layer I/S: (A) Lath-like illite that cover the framework of grains, Dibeilla W-1 , 1413m, E2; (B) Mat-like illite with local fibrous termination, Agadi-3, 2030.5m, E1; (C) Lath-like illite that cover the framework of grains, Faringa-1, 2397m, E2; (D) Grain-surface illite associated with kaolinite, Sokor E-1, 1759.4m, E2; (E) Grain-surface mixed-layer I/S as replacement of detrital feldspar, Dougoule-1, 1154m, E2; (F) Grain-surface mixed-layer I/S with an extinct of mud matrix replacement, Tamaya-1, 925m, E1; (G) Honeycomb-like grain-coating I/S with relic pores, Agadi E-1, 2505m, E5; (H) Honeycomb-like grain-coating I/S and a large amount of micropores, Imari-1, 1375m, E5

\section{Discussion}

\subsection{Diagenetic history}

The Sokor1 sandstones have undergone multiple diagenetic modifications that accentuated the spatial and temporal distribution of reservoir quality. These modifications seem to be closely related to depositional facies, oil emplacement and the basin subsidence and uplift history. Due to the latter, two distinct parts (Dinga fault Terrace, SW and Araga Graben, NE) (Fig.4) of the basin could have different diagenitic stages division. Through detailed research on thin sections, SEM and XRD, the diagenetic sequence of sandstone in Sokor1 formation of Agadem Block, Termit Basin could be reconstructed by considering (1) Burial depth, (2) diagenetic minerals, (3) homogenization temperature of fluid inclusions and (4) mixed layer minerals (illite/smectite) based on the China National Standards of Oil and Gas Industry (SY/T5477-2003) standard. For diagenetic stages reconstruction we used smectite percentage (S\%) (Table 2) in the mixedlayer illite/smectite rather than vitrinite reflectance (which is lack) to calibrate the thermal history of organic matter (OM) as demonstrated in detail by Berger et al. 1997, Wei et al. 1996, Lanson et al. 2009, and Li et al. 2016. We also take into account the study of the source rock thermal maturity and burial history by Harouna \& Philp 2012, Wan et al. 2014, Liu et al. 2015 and Harouna et al. 2017 to 
constrained the thermal history of the Sokor1 sandstones. It is believed that the Sokor1 formation in the study area is at the stage A of middle diagenesis, except a few parts at the stage B of early diagenesis (Fig.21 and Fig.22).
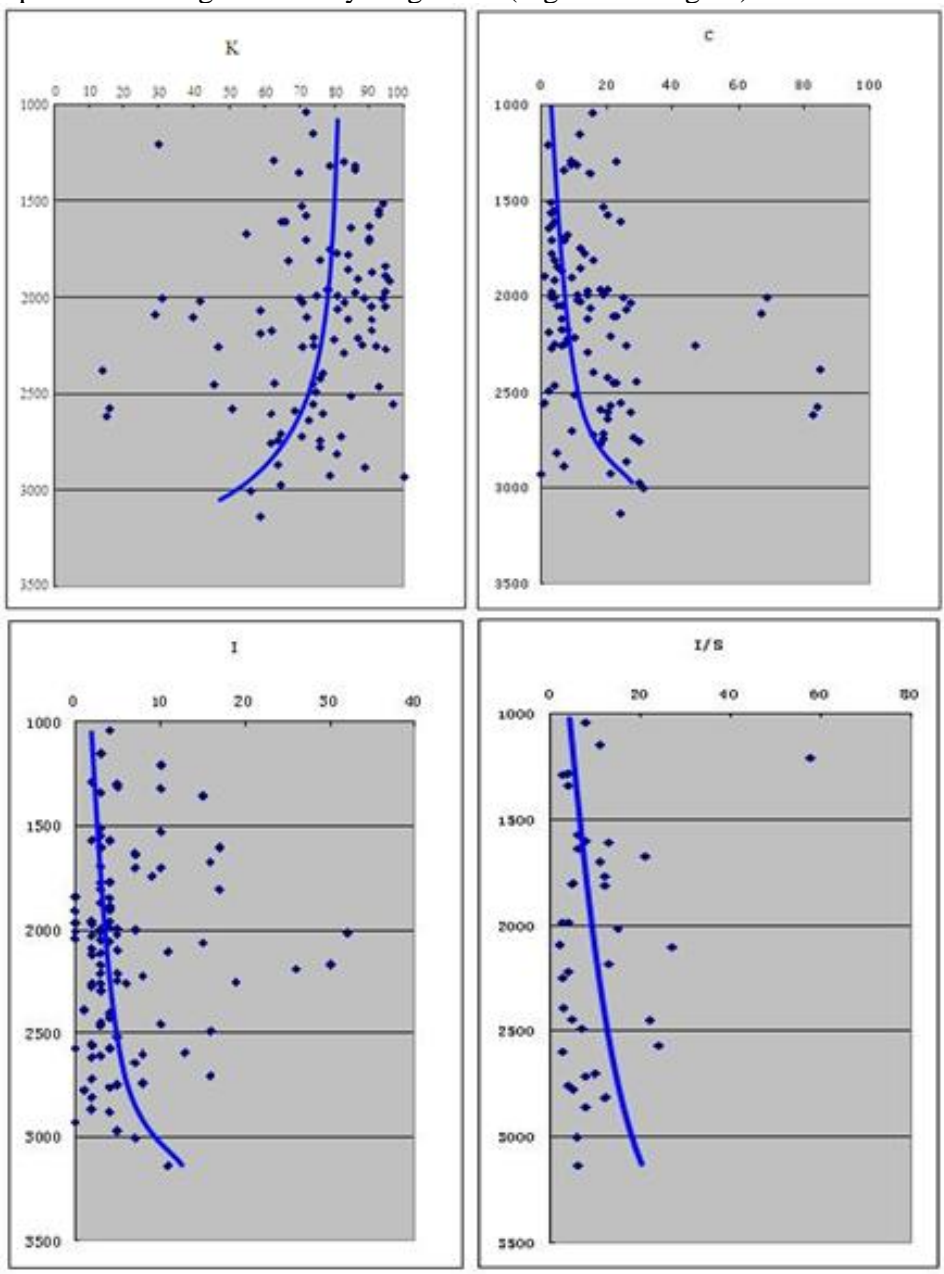

Fig.16. Clay minerals content versus depth in Sokor1 sandstones, Termit Basin (K= Kaolinite, $\mathrm{C}=$ chlorite, $\mathrm{I}=\mathrm{illite}, \mathrm{I} / \mathrm{S}=\mathrm{illite} / \mathrm{smectite})$
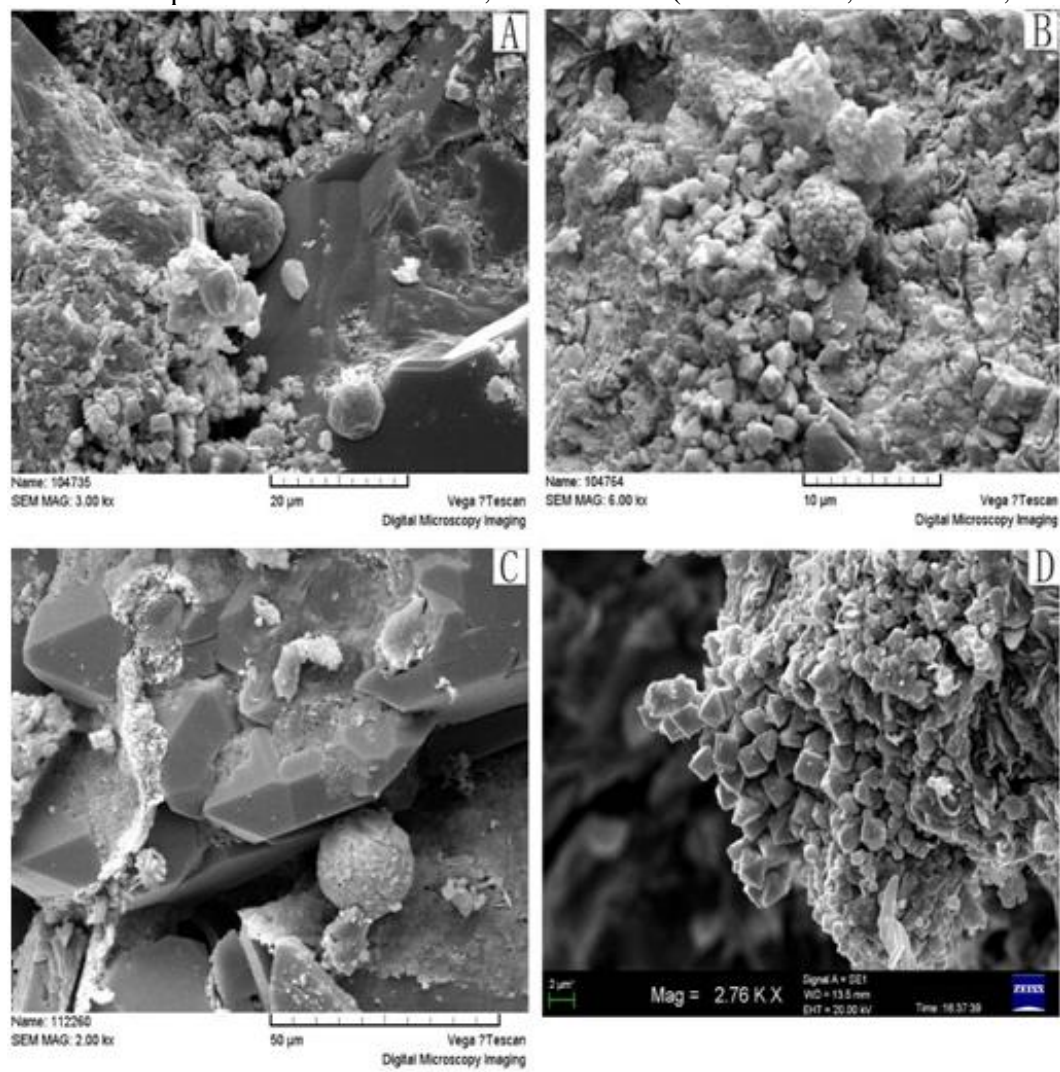

Fig.17. Scanning electron micrographs showing character of pyrite: (A) Framboids pyrite growing on a detrital feldspar grain, Goumeri SE-1, 1963.5m, E1; (B) Pyrite with intermediate textures between framboid and euhedral, Madama NW-1, 1602m, E5; (C) Pyrite associated with quartz overgrowth, Agadi-2, 2010.2m, E2; (D) Pyrite displays octahedral crystals, Dibeilla-1, 1390m, E2 

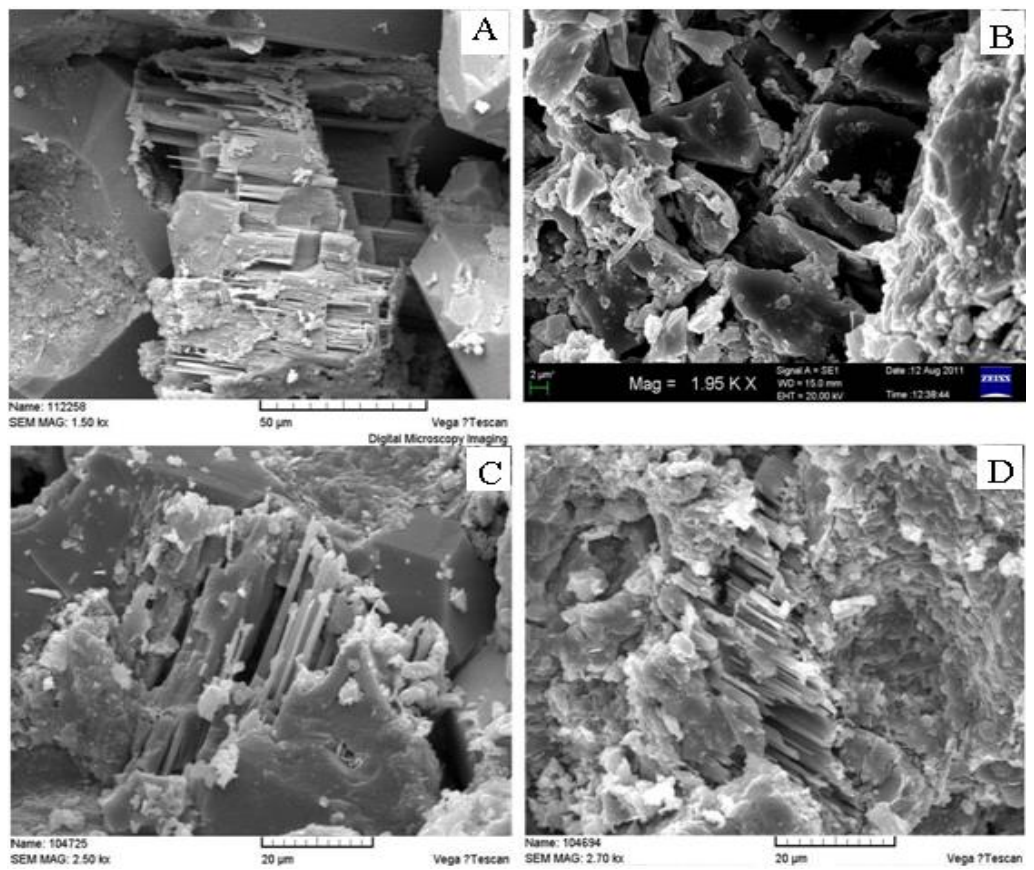

Fig.18. Scanning electron micrographs showing dissolved feldspar and quartz grains (A) Cast pores on dissolved detrital feldspar grain, Agadi-2, 2010.1m, E1; (B) Intra-pores on dissolved quartz grains, Dougoule-1, 1245m, E2; (C) Hull pores on dissolved detrital feldspar grain (fenester texture), Agadi-3, 1986.5m, E1; (D) Rib-like pores on remains feldspar grain (cancellate texture), Admer-1, 1857.5m, E5
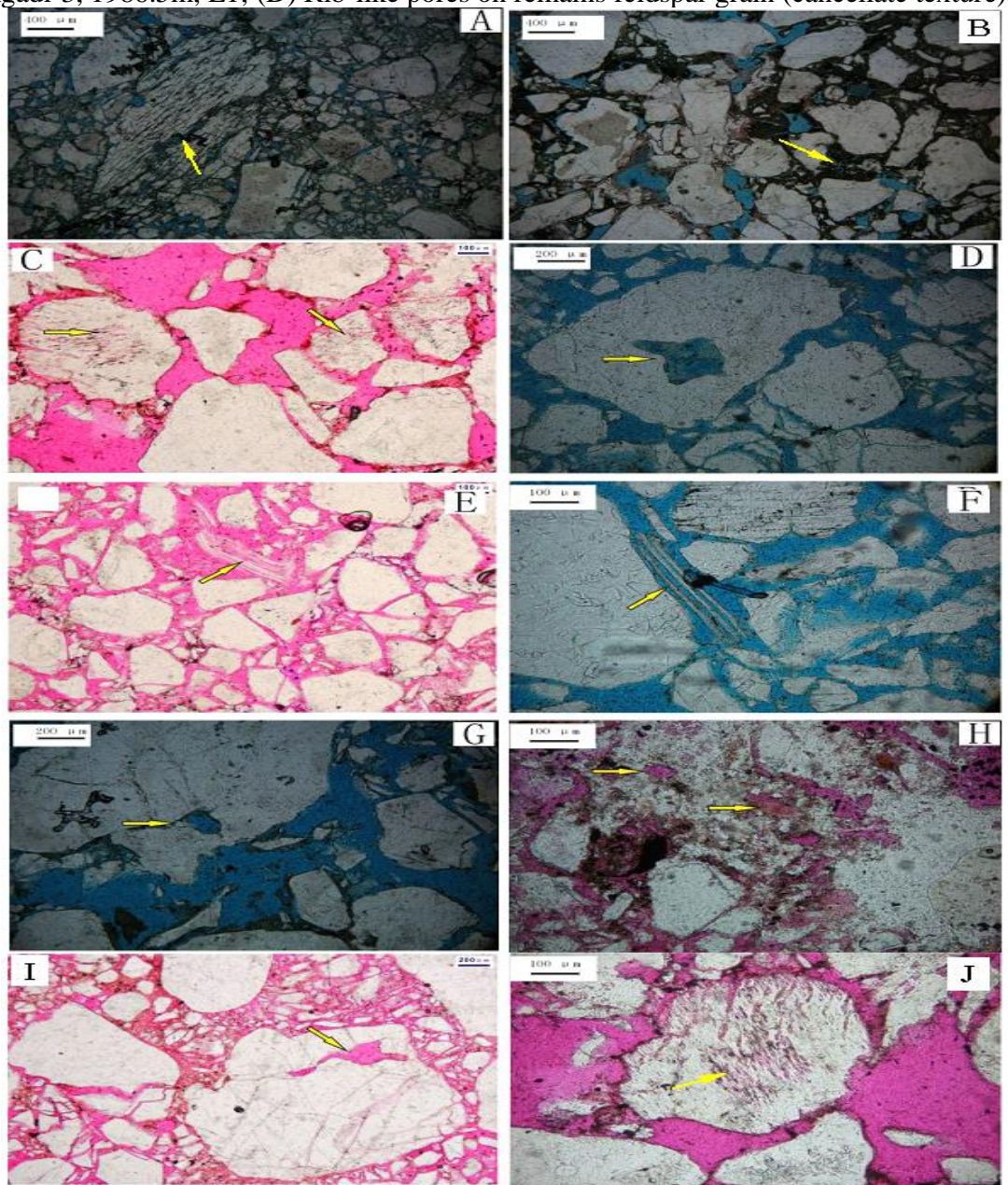

Fig.19. Thin-section photomicrographs showing dissolution and secondary porosity (in blue and red color) (A) Anisomerous quartz sandstone, dissolved feldspar with intra-grain pores (arrow), Agadi-2, 2010.1m, E1; (B) Anisomerous quartz sandstone, dissolved matrix with inter-grain pores, Dougoule E-1, 2286m, E4; (C) Coarse-grain quartz sandstone, dissolved feldspar with intra-grain pores and oversize pores, Karagou-1, 1891m, E3; (D) Anisomerous quartz sandstone, dissolved quartz with intra-grain pores, Dougoule-1, 1245m, E2; (E) Medium-grain quartz sandstone, dissolved mica with intra-grain pores, Admer-1, 1744m, E4; (F) Coarse-grain quartz sandstone, dissolved mica and quartz with intra-grain pores, Sokor-7, 1846m, E2; (G) Anisomerous quartz sandstone, dissolved quartz with intra-grain pores, Goumeri SE-1, 2091m, E2; (H) Anisomerous quartz sandstone, dissolved quartz with intra-grain pores, Dougoule w-1, 1317.5m, E3; (I) Anisomerous quartz sandstone, dissolved quartz with intra-grain pores, Madama NW-1 , 1691m, E5 ; (J) Anisomerous quartz sandstone, dissolved feldspar with intra-grain pores and oversize pores, Dibeilla N-1, $1211 \mathrm{~m}, \mathrm{E} 2$ 


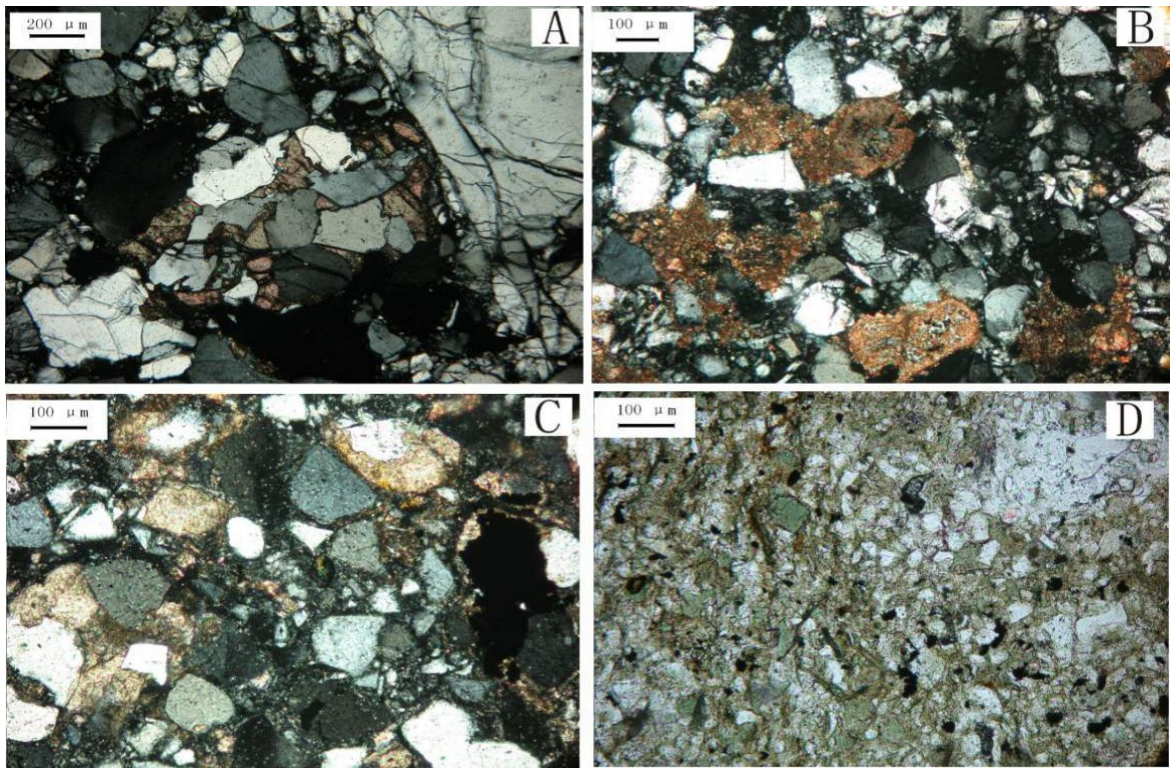

Fig.20. Thin-section photomicrographs of Sokor1 sandstones showing the effects of replacement: (A) Medium-grained quartz with calcite alternates quartz grains, Goumeri-2, 2869.5m, E4; (B) Fine-grained quartz with calcite alternates quartz grains and matrix, Goumeri-3, 2389.9m, E1; (C) Fine-grained quartz with calcite alternates quartz grains, Tamaya-1, 926m, E1; (D) Muddy siltstone with chlorite alternates muddy debris, Sokor E-1, 1678.6m, E1

\subsubsection{Stage $B$ of eodiagenesis}

The sandstone structure is loose, dominated by point contact with abundant initial pores, mainly primary inter-pores. The burial depth became larger and larger but less than $2000 \mathrm{~m}$ (E1 interval). The cement content in the sandstone is not very high, generally dominated by clay minerals, some early quartz growth and early carbonate cements such as calcite and dolomite. The overgrowth level of quartz is level I, rarely seen in the thin section. Mechanical compaction is strengthened and reduced much more primary porosity (Fig.6C and D). Under SEM, quartz crystallite could be seen, taking on sparse or connected incomplete crystal plane. The clay minerals in the mud-rock are mainly mixed-layer I/S and kaolinite, showing random structure. The kaolinite precipitated as coating around most of detrital grains suggesting the pore-water medium environment is weak organic acid. This condition is favorable for leaching of feldspar grains which could be source material of kaolinite. In the mixed-layer I/S, smectite accounts for $50 \%$ to $60 \%$ indicating semi-mature OM and the paleo-temperature experienced by the formation is $65^{\circ} \mathrm{C} \sim 85^{\circ} \mathrm{C}$, equivalent to the marker and features of stage $\mathrm{B}$ of eodiagenesis (SY/T5477-2003).

\subsubsection{Stage A of mesodiagenesis}

With progressive and rapid increase in burial depth $(>2000 \mathrm{~m} \sim 3000 \mathrm{~m})$, the studied sediments entered the mesodiagenetic regime. In addition to temperature $\left(85^{\circ} \mathrm{C} \sim 140^{\circ} \mathrm{C}\right)$ and pressure increase and spatial to temporal distribution of mesodiagenetic alterations, the enhancement of porosity and permeability evolution in Sokor1 sandstones were influenced by eodiagenetic modifications and probably by oil emplacement. During stage A of mesodiagenetic, mechanical compaction increase caused grains packing, bending and rupturing of mica grains and plastic deformation of ductile mud-rock fragments and mud intra-clasts forming pseudo-matrix. The diagenetic minerals include, secondary quartz overgrowth with level II and many self-generation quartz crystals, siderite, pyrite, kaolinite, illite, mixed-layer I/S and chlorite acted as cement. The clay minerals in the mud-rock are mainly pores filling kaolinite, illite occluding pore spaces, chlorite as rims and $\mathrm{I} / \mathrm{S}$ as pore-lining. S\% in I/S accounts for $15 \%$ to $25 \%$ indicated the low-mature to mature stage of OM which led to mainly acidic environment in pore water (Lanson et al. 2002). At this stage, the organic matter produced large amounts of hydrocarbon and released enormous organic acid and $\mathrm{CO}_{2}$, leading to water medium becoming more acid, resulting in the dissolution of aluminosilicate and carbonate (simultaneous dissolution and precipitation), forming enormous secondary pores and improving physical properties in the reservoir. It is predicted that the Sokor1 Formation did not rich stage B of Mesodiagenesis due to the partial dissolution of detrital feldspar grains rather than the complete dissolution which required high temperatures (Morad et al. 2000) than those attained by Sokor1 sandstones.

Table: 2: Ratio Range of S\% in Mixed-Layer I/S of Paleogene Sandstone in Agadem Block, Termit Basin

\begin{tabular}{llll}
\hline Horizon & Samples number & s\% in I/S & Remarks \\
\hline E1 & 13 & $20-45$ & Mainly at 25\%, 60\% in Well Madama NW-1 \\
E2 & 19 & $12-40$ & Mainly at 25\% \\
E3 & 5 & $20-30$ & Mainly at 20\% \\
E4 & 16 & $20-40$ & Mainly at 20\% \\
E5 & 9 & $20-40$ & Mainly at 20\% \\
\hline
\end{tabular}

\section{2. Sources of mineral cements}

In the Paleogene Sokor1 reservoirs, pyrite shows framboidal and intermediate textures between framboid and euhedral textures suggesting that pyrite was almost the result of bacterial sulphate reduction in marine environments. In this context, sulphate is assumed to be supply from the ambient seawater and the iron was supplied by the localized reduction of detrital ferric detritus (Berner 1981, Morad 1986). Therefore the carbonate cements will have been derived from dissolved and locally re-precipitated detrital carbonate grains, bioclasts, etc. This interpretation can be supported by the fact that shallowest samples have the greatest quantity of discernible early carbonate (calcite) but none are visible in the deepest samples. Such dissolution of carbonate grains or bioclasts implies relative high tem- 
perature and large amounts of organic acids and $\mathrm{Co}_{2}$ from thermal evolution of organic matter (Dutton 2008) which providing carbon. The sources of $\mathrm{Ca}$ and $\mathrm{Mg}$ ions for the deepest carbonate (siderite) in Sokor1 sandstones has presumably been sourced from large amounts of advective compaction fluids which were expelled from mudstones or derived from the alteration of mud intra-clasts and illitization of smectite in the interbedded clay during mesodiagenesis (Morad 1998, Rossi et al. 2001). Precipitation of silica cement as authigenic quartz, kaolinite, illite and chlorite occurred in the mesodiagenetic stage (Yuan et al. 2015). According to some authors interpretation the authigenic clay may have several origins including: inherited coats (Wilson 1992), infiltrated clays (Moraes \& De Ros 1990), bioturbation (Wilson \& Pittman 1977) and the acts of sediment ingestion and excretion (Needham et al. 2004, 2005). In this studied sandstones, no sign of inherited coats and infiltrated clays have been reported due to the lack of recrystallized clay minerals. The origin of the eodigenetic kaolinite is assumed to be the bioturbation as it was identified in primary inter-grains pores. With the increase of burial depth, kaolinite precipitated as byproducts from the dissolution of detrital feldspar grains and mica. The positive relationship between the amount of secondary pores and clays observed on the thin section and SEM scale suggest that the dissolution of feldspar is the source of the authigenic clays in Sokor1 sandstones. Also illite and chlorite are originated from the transformation of kaolinite and mixed-layer illite/smectite as shown in figure 16. The silica cement was sourced from the illitization of smectite in I/S layer and kaolinitization of detrital K-feldspar and quartz grains dissolution (Worden \& Morad 2000). The overgrowth of quartz associated whit kaolinite suggest that the feldspar dissolution is a potential way of silicon dioxide source for quartz cementation (Fig.13 A and C). Other potential source of silica was presumably the closely-associated to the inter-granular pressure dissolution of detrital quartz as indicated by the presence of concavo-convex contacts between quartz grains itself and also sutured contacts.

\begin{tabular}{|c|c|c|c|c|c|c|c|c|c|c|c|c|c|c|c|c|c|c|}
\hline $\mathscr{c}^{\infty}$ & & Diage & nesis & $\overrightarrow{8}$ & & & & & & $\begin{array}{c}\text { Diag } \\
\text { Mir }\end{array}$ & $\begin{array}{l}\text { genetic } \\
\text { nerals }\end{array}$ & & & & Disso & plution & & \\
\hline 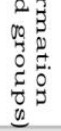 & Depth & Type & Stage & 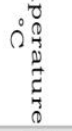 & $\begin{array}{l}\mathrm{S} \% \\
\text { in } \\
\mathrm{I} / \mathrm{S}\end{array}$ & $\begin{array}{l}\text { Sandstone } \\
\text { Consolidation } \\
\text { Degree }\end{array}$ & 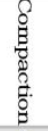 & $\mathrm{I} / \mathrm{S}$ & Illite & Chlorite & Kaolinite & $\begin{array}{l}\text { Q Quartz } \\
\text { overgrowt }\end{array}$ & Calcite & Siderite & 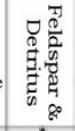 & Carbonate & 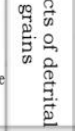 & $\begin{array}{l}\text { Pore } \\
\text { Types }\end{array}$ \\
\hline E 1 & $\begin{array}{c}1200 \\
\sim \\
1300 \\
\end{array}$ & 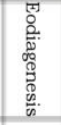 & B & $\begin{array}{c}65 \\
\sim \\
85 \\
\end{array}$ & $\begin{array}{c}50 \\
\sim \\
60 \\
\end{array}$ & 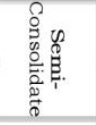 & & 1 & & & & $\begin{array}{l}\text { I } \\
\text { I } \\
\text { int }\end{array}$ & & $\begin{array}{l}1 \\
1\end{array}$ & 1 & 1 & $\begin{array}{l}\text { Point } \\
\text { Contact }\end{array}$ & 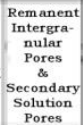 \\
\hline E2 & $\begin{array}{c}1300 \\
\sim \\
1450 \\
\end{array}$ & & & & & & & 1 & & & & I & & 1 & $\begin{array}{l}1 \\
1\end{array}$ & $\begin{array}{l}1 \\
1\end{array}$ & $\begin{array}{l}\text { Point } \\
\text { Contact }\end{array}$ & \\
\hline E3 & $\begin{array}{c}1450 \\
\sim \\
1550\end{array}$ & $\begin{array}{l}3 \\
0 \\
0 \\
0 \\
8\end{array}$ & & 85 & 15 & $\delta_{0}$ & & I & & & & & & 1 & 1 & $\begin{array}{l}1 \\
1\end{array}$ & & 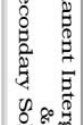 \\
\hline E4 & $\begin{array}{c}1550 \\
\sim \\
1650 \\
\end{array}$ & $\begin{array}{l}{ }_{0}^{2} \\
0 \\
0 \\
0 \\
0 \\
0 \\
0\end{array}$ & A & 140 & 25 & 尊 & & I & & & & & & & 1 & 1 & & 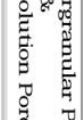 \\
\hline E5 & $\begin{array}{c}1650 \\
\sim \\
1800\end{array}$ & is & & & & & & & & & & & & & 1 & & $\begin{array}{l}\text { Line } \\
\text { Contact }\end{array}$ & 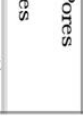 \\
\hline
\end{tabular}

Fig. 21. Division of Diagenetic Stage In Dibeilla Aera of Termit Basin

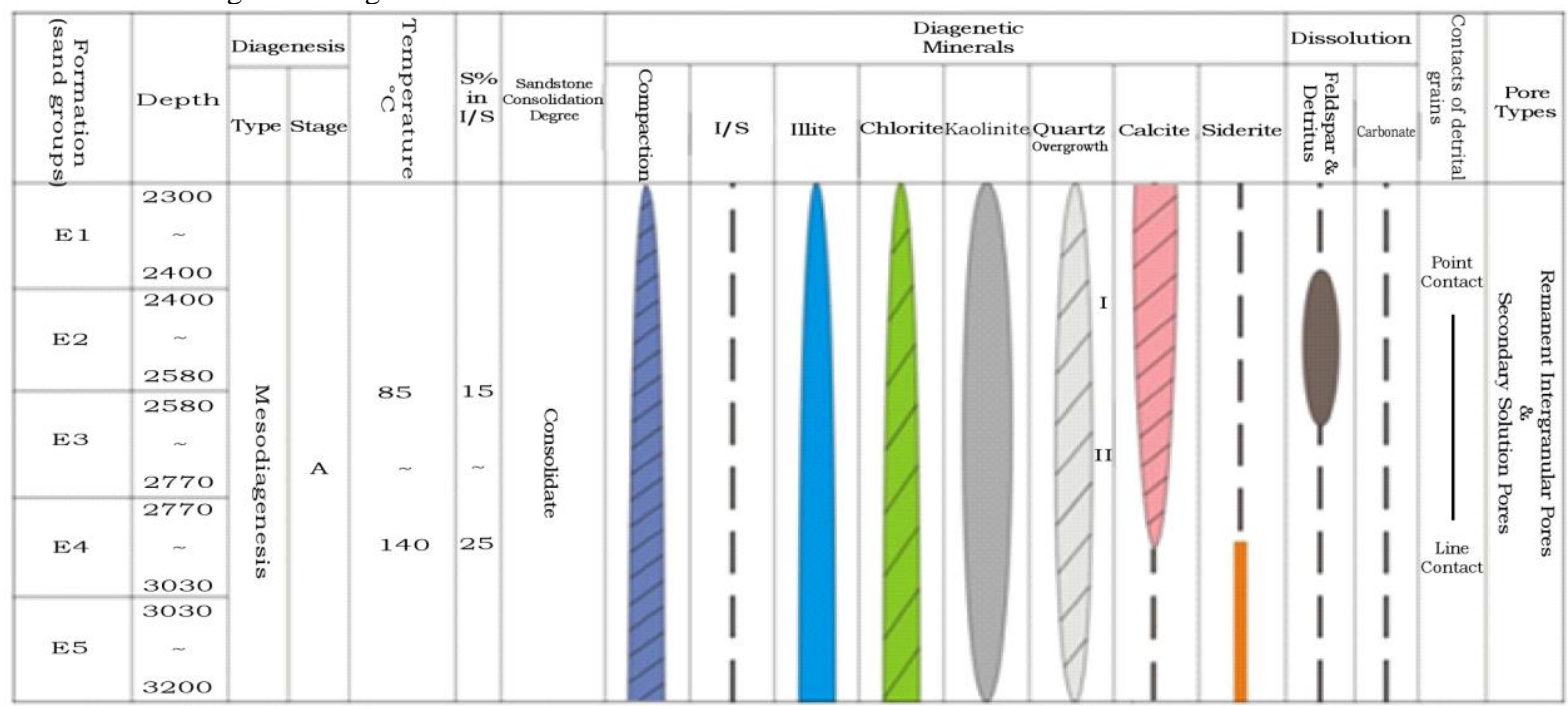

Fig. 22. Division of Diagenetic Stage In Imari E-1-Dinga Deep Aera of Termit Basin

\subsection{Reservoir evaluation in sokor1 formation}

\subsubsection{Features of reservoir space}

The quality of pore structure is an important criterion to evaluate the reservoir which has close relations to the reservoir property. The so called pore structure refers to the symmetry, size, distribution and pores inter-connection relations and pore throats (Bliefnick \& Kaldi 1996). In one hand, generally, the enclosed large space formed by grains is called as pore which is the basic space to preserve fluid and reflecting the reservoir capacity. At other hand, the narrow path between two grains is called as pore throat, collectively making up the pore network. The pore throat is the major path to control the seepage of the fluid in rocks and its distribution and pattern are major fac- 
tors influencing the reservoir permeability. Therefore the analysis and identification of pore structures and features as well as evolutional rules is a major link to look for and estimate the favorable reservoir rock in this kind of study. By the latter, the reservoir space Features of studied area included pore types, types of pore throats and thin section porosity.

1) The pore types in Sokor1 sandstones developed as primary and secondary pores. Primary pores refer to primary inter-grain pores from the connate deposition of rocks, remain of compaction and cementation and preserved till now. They are the most develop pores in reservoir of Sokor1 Formation (Fig. 23). The latter has wide pore throats and good connectivity. Therefore, the reservoir capacity and seepage capacity are good. Secondary pore is made from feldspar, quartz, clay minerals and matrix under dissolution as well as replacement, including various denudated pores (inter-grain denudated pore, intra-grain denudated pore, and oversized pore), inter-crystal pore and fissures. The inter-grain denudated pores and fissure pores are formed from dissolved inter-grain fillings such as muddy content or fake matrix during the diagenetic process (Fig. 23I and J). The denudated intra-grain pores of feldspar, mica and quartz are commonly seen (Fig. 19). Inter-crystal pore refers to the micropores between small crystals of kaolinite which, the connectivity is poor and has minor significance to reservoir permeability (Fig.13 A and B). Under SEM, partial dissolution of feldspar grains in Sokor1 sandstones suggesting oversized pores chiefly formed by its complete dissolution (Fig.18 A, C and D). It is also possible that a few oversized pores were formed by rock fragments and unstable heavy minerals dissolution. Fissure porosity is not widespread in the studied sandstones (Fig.23J).

2) Based on the proportionality assumption between pore types and throats from the thin section analysis and by taking into account the fact that porous network modification must be largely due to changes in pore throats (Robert Ehrlich \& Edward L. Etris 1990), three types of pore throats were identified in Sokor1 sandstone including undisrupted pore throats, disrupted pore throats and cluster pore throats. (i) Undisrupted pore throats developed in clastic reservoir dominated by inter-grain pores or associated with extralarge pores (Fig.24A and B). It exists normally in the pore systems with low cementation, structure supported by matrix, sandstone with point contact, moderate to well sorted and no significant modification in the depositional fabric due to the high contain of quartz grains. (ii) Disrupted pore throats are the squeezed or filled pore throat when sandstone is compacted or cement precipitated. Its porous network shows structure dominated by point - linear contact. It is commonly seen in the pore system with grain-support structure and pore-type cementation (Fig. 24C and D). (iii) The cluster pore throats defined here as continuous pore spaces without any contact between each other and may consist of various individual pores. It is commonly seen in the pore systems with high matrix or cements content and suture contact sandstones (Fig. 24E and F). The latter means low porosity and very low permeability. Whereas the second and first kind of pore throats lead to high porosity but low permeability and high porosity and high permeability respectively.

3) Thin section porosity refers as the ratio between total pore space area on a thin section and total perimeter that encloses the porespace. It is an important feature used to analyze the reservoir capacity (Weger et al. 2009). Based on the over 90 cast slices as well as observation under SEM, the surface-pore features of each horizon of E1-E5 are obtained. E1 has the lowest thin section porosity, averaging $14.7 \%$ and the average thin section porosity of E2-E5 is near $20 \%$ (Table 3). Considering the fact that both pore type and throat size are determined by the internal (grain size and sorting) and external (size, shape and arrangement) properties of domains (Weger et al. 2009), the statistics and comparison of thin section porosity of over 90 cast slices was made according to the sedimentary micro-facies of the study area. It is discovered that the average thin section porosity is the highest in underwater distributary channel sand body and mouth bar sand body in sub-facies of delta front as well as the distributary channel sand body in delta plain (Table 4). The average thin section porosity of underwater distributary channel sand body is $19.5 \%$, that of mouth bar sand body is $17.6 \%$, and that of the distributary channel sand body is $18.9 \%$. The ratio at distal bar and shallow-lake bank-bar is low, blew $10 \%$ (Table 4).

Table 3: Thin Section Porosity Ratio of Each Sand Group in Paleogene Sokor1 Formation, Termit Basin

\begin{tabular}{lllll}
\hline Horizon & Sample quantity. & $\begin{array}{l}\text { Max. thin section porosity } \\
\text { ratio }\end{array}$ & $\begin{array}{l}\text { Min. thin section porosity } \\
\text { ratio }\end{array}$ & $\begin{array}{l}\text { Aver. Thin section porosity } \\
\text { ratio }\end{array}$ \\
\hline E1 & 7 & 35 & 3 & 14.7 \\
E2 & 49 & 35 & 2 & 17.4 \\
E3 & 23 & 35 & 5 & 19.4 \\
E4 & 15 & 30 & 5 & 18.6 \\
E5 & 6 & 20 & 15 & 17.8 \\
\hline
\end{tabular}

Table 4: Thin Section Porosity Ratio Features in Different Sedimentary Micro-Facies of Paleogene Sokor1

\begin{tabular}{llll}
\hline Micro-facies & Sample quantity. & $\begin{array}{l}\text { Distribution range of thin section } \\
\text { porosity \% }\end{array}$ & Aver. thin section porosity ratio \% \\
\hline Distributary channel of delta plain & 7 & $12-25$ & 18.9 \\
Underwater distributary channel in delta front & 70 & $2-35$ & 19.5 \\
Mouth bar in delta front & 11 & $10-24$ & 17.6 \\
distal bar in delta front & 3 & $2-10$ & 8.7 \\
Shallow-lake bank bar & 4 & $2-12$ & 9.5 \\
\hline
\end{tabular}

\subsubsection{Reservoir properties}

As the core samples taken from borehole wall (sidewall core) are small and sometime loose, it is impossible to conduct the assay and tests for porosity and permeability therefore, its evaluation in each sand group were based on the logging data. The thickness of E1 sand group is between $1 \mathrm{~m} \sim 53.6 \mathrm{~m}$, averaging at $12.8 \mathrm{~m}$, and most is $15 \mathrm{~m} \sim 30 \mathrm{~m}$ and within this thickness the sand/formation ratio is between $0.1 \sim 0.48$, most between $0.15 \sim 0.3$. The porosity and permeability of it are $11.6 \% \sim 27 \%$, and $23 \mathrm{md} 250 \mathrm{md}$ respectively. E2 reservoir sand group thickness is $1.2 \mathrm{~m} \sim 90 \mathrm{~m}$, averaging at $32.69 \mathrm{~m}$, and most is $20 \mathrm{~m} \sim 40 \mathrm{~m}$; the sand/formation ratio is $0.1 \sim 0.48$, most between $0.2 \sim 0.4$; the porosity is $13 \% \sim 27 \%$, and permeability is $41 \mathrm{md} \sim 251 \mathrm{md}$. The reservoir evaluation of E3 Sand group reveals porosity between $11 \% \sim 25 \%$, and permeability of $20 \mathrm{md} \sim 244 \mathrm{md}$. Its thickness is $1.8 \mathrm{~m} \sim 72.9 \mathrm{~m}$, averaging at $32.54 \mathrm{~m}$, and most is $22 \mathrm{~m} \sim 50 \mathrm{~m}$ and the sand/formation ratio is $0.1 \sim 0.53$, most between $0.15 \sim 0.3$. E4 Sand group thickness is $21.1 \mathrm{~m} \sim 67.9 \mathrm{~m}$, averaging at $44 \mathrm{~m}$, and most is $30 \mathrm{~m} \sim 60 \mathrm{~m}$; the sand/formation ratio is $0.12 \sim 0.45$, most between $0.2 \sim 0.35$ and has porosity of $11 \% \sim 25 \%$, and permeability of $30 \mathrm{md} \sim 287 \mathrm{md}$. Finally the thickness of E5 sand group is $20 \mathrm{~m} \sim 127 \mathrm{~m}$, averaging at $49.15 \mathrm{~m}$, and most is $40 \mathrm{~m} \sim 70 \mathrm{~m}$; the sand/formation ratio is $0.15 \sim 0.84$, most between $0.3 \sim 0.6$; the porosity is $12 \% \sim 25 \%$, and permeability is $14 \mathrm{md} \sim 308 \mathrm{md}$.

Based on the evaluation standard (Table 5), the reservoir of the study area could be divided into 3 types, namely: type-I reservoir of high and medium porosity and permeability (Dibeilla, Faringa and Dougoule areas), type-II of low porosity and permeability (Dinga Deep 
area in few sand group intervals) and type-III of extra-low porosity and permeability. Reservoir of medium porosity and permeability accounts for $56 \%, 80 \%, 74 \%, 78 \%$ and $67.3 \%$ in E1-E5 respectively. The integration of these petrophisical properties with thin section porosity data shows that sand body in distributary channel, underwater distributary channel as well as mouth bar in delta facies could be seen as type-I reservoir, sand body of distal bar and shallow-lake bank bar could be seen as type-II reservoir, and muddy siltstone could be seen as type-III reservoir.
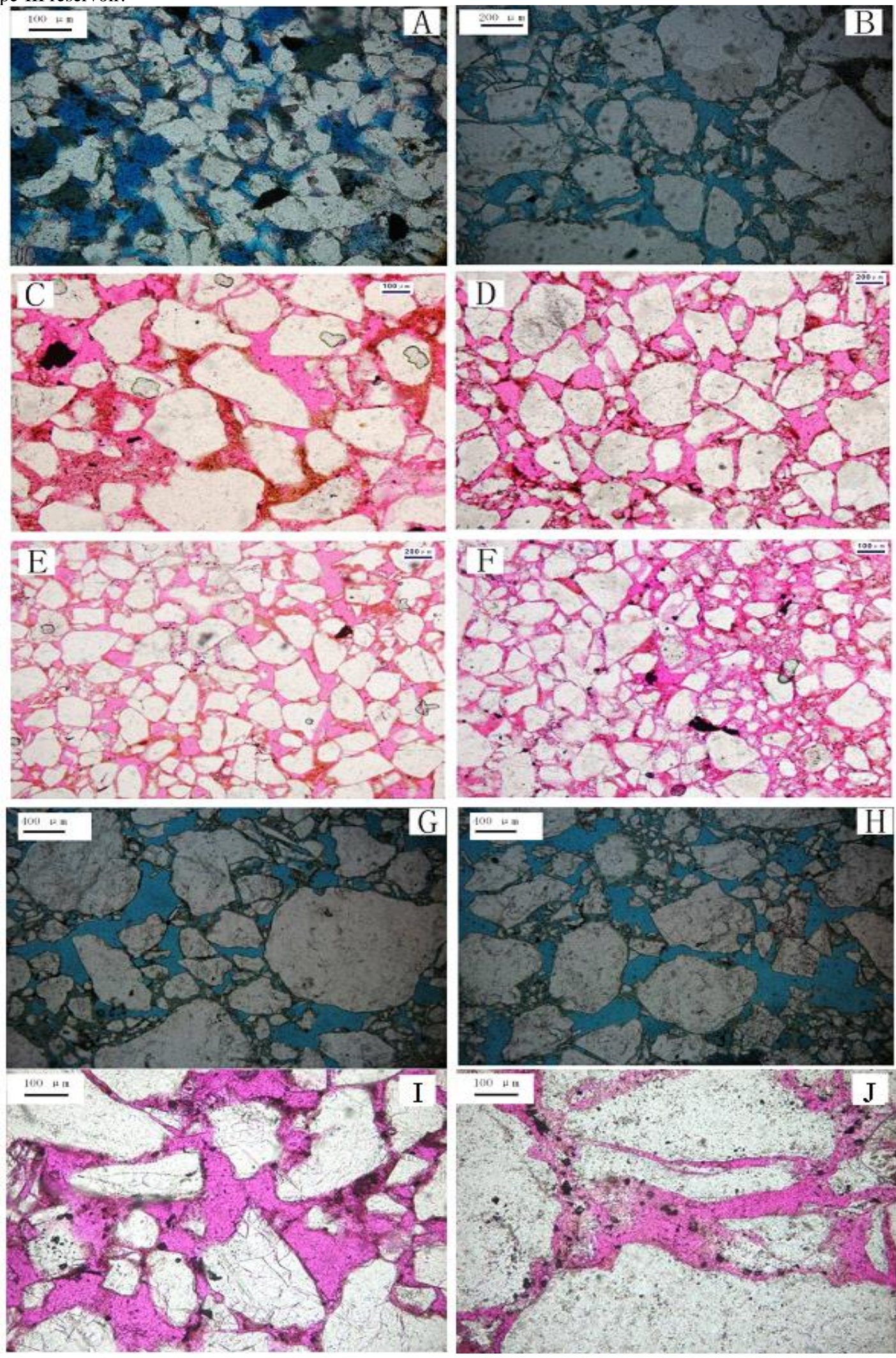

Fig. 23.Thin-section photomicrographs indicating primary inter-grain pores (in blue and red color, note dominance of point-contacts) in Sokor1 sandstones: (A) Fine-grain quartz sandstone, Agadi-2, 1999.5m, E2; (B) Medium-grain quartz sandstone, Sokor S-1 2191m, E4; (C) Medium-grain quartz sandstone, Dibeilla N-1, 1714m, E5; (D) Medium-grain quartz sandstone, Dibeilla W-1, 1500m, E3; (E) Fine -grain sandstone, Ounissoui-1, 1260m, E4; (F) Fine-grain sandstone, Sokor E-1, 1782.5m, E1; (G) Anisomerous quartz sandstone, Bougoure-1, 1687.1m, E2; (H) Medium-grain quartz sandstone, Bougoure-1, 1687.1m, E2; (I) Medium-grain quartz sandstone, Dougoule E1, 1348m, E3 ; (J) Coarse-grain quartz sandstone Dibeilla W-1, 1385.5m,E2 
Table 5: Evaluation Standard of Porosity and Permeability in Oil-Bearing Clastic Reservoir (SY/T6282-1997)

\begin{tabular}{llll}
\hline Reservoir type & Porosity $(\%)$ & Permeability $\left(10^{-3} \mu \mathrm{m}^{2}\right)$ & Evaluation \\
\hline Extra-high porosity and permeability & $>30$ & $>2000$ & $2000-500$ \\
High porosity and permeability & $30-25$ & $500-50$ & $\mathrm{I}$ \\
Medium porosity and permeability & $22-15$ & $50-10$ & $\mathrm{II}$ \\
Low porosity and permeability & $12-10$ & $<10$ & III \\
Extra-low porosity and permeability & $<10$ & & II \\
\hline
\end{tabular}
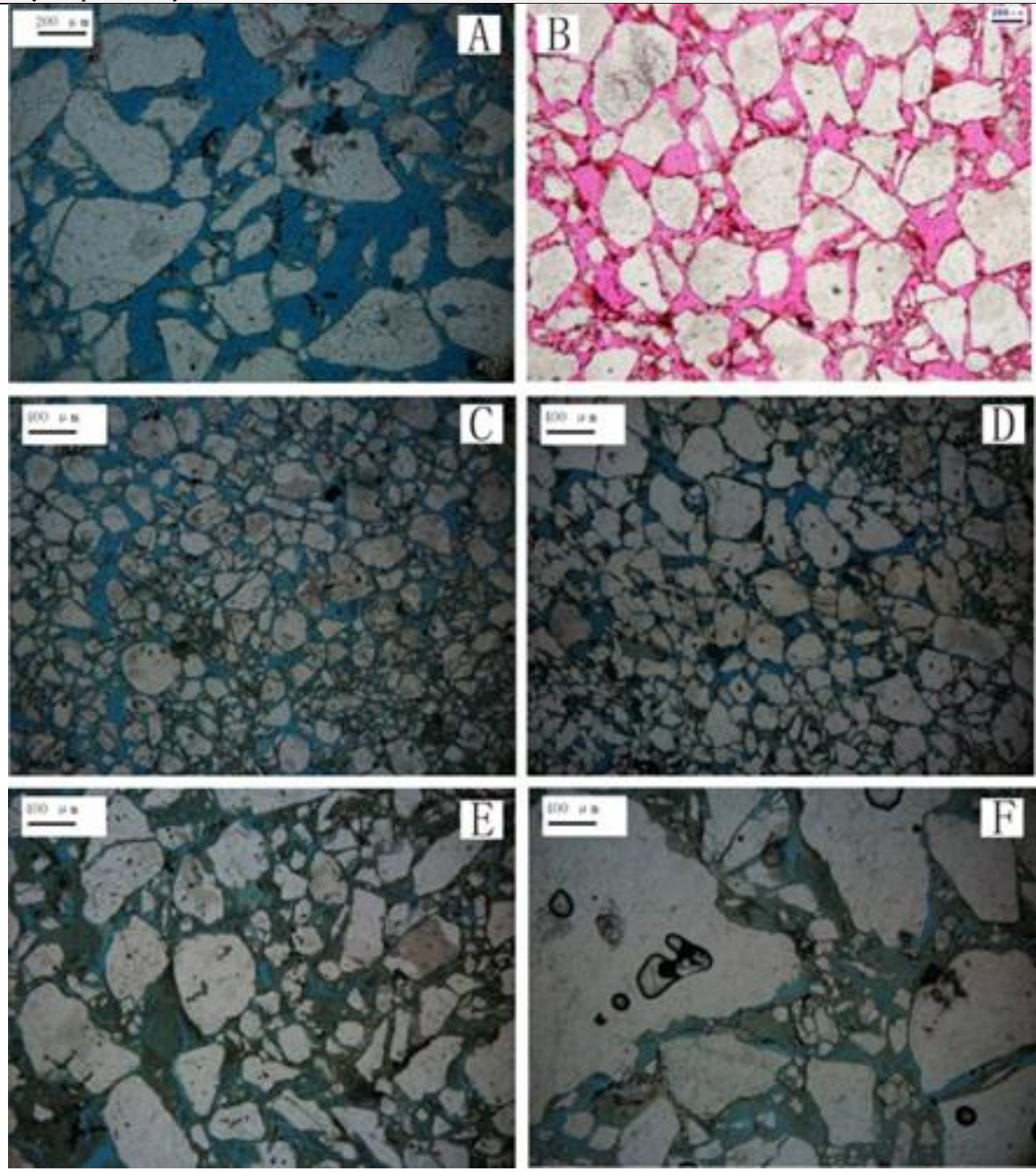

Fig. 24. Thin-section photomicrographs indicating pore throats development in Sokor1 sandstones: (A) Medium-grain quartz sandstone, Sokor-7, 1754m, E1; (B) Medium-grain quartz sandstone, Dibeilla W-1, 1500m, E3; (C) Fine-grain quartz sandstone, Imari W-1, 1316.7m, E4; (D) Fine-grain quartz sandstone, Sokor-7, 1963.5m, E3; (E) Anisomerous quartz sandstone, Faringa W-1, 1957m, E2; (F) Coarse-grain quartz sandstone, 1998m, E2

\subsection{Implications for reservoir quality}

Reservoir quality defined here as petrophysic parameters (porosity and permeability) of Sokor1 sandstones, can be a function of original mineral composition or provenance and depositional controls on grain size and sorting as well as diagenetic controls of compaction, cementation, dissolution and development of authigenic clays minerals (Schmid et al. 2004, Islam 2009, Rahman \& McCann 2012). In the Sokor1 sandstones, these up-cited properties affected the grain-pore relationship and characteristics of pore-pore throat. Sokor1 Formation developed delta and lake sedimentation in which the major sedimentary micro-facies includes distributary channel, underwater distributary channel, mouth sand bar, distal bar and shallow-lake bank bar. Therefore, the best quality reservoir rocks were located in distributary channel, underwater distributary channel and distal bar with large thickness of sand body, medium to coarse grain size, moderate sorting, high percentages of detrital quartz grain and low content of matrix and cements leading to good physical property. The mouth sand bar and shallow-lake bank bar has small thickness of sand body, poor sorting and the grains are fine, mainly at the level of siltstone. The high muddy content of it leads to poor physical property. 
In accordance with the mineralogical compositions differential degree of compaction occur in Sokor1 sandstones. The high content of quartz in the matrix decides that the rock types of reservoir are mainly quartz sandstone, which leads solid foundation for the development of efficient reservoir. Also, due to the high content of rigid quartz grains, its anti-pressure is strong and the original pore could be easily preserved, thus the most important pores in Sokor1 sandstones are primary intergranular pores.

The reservoir quality of the Termit Basin in Sokor1 Formation was significantly controlled by diagenesis. The main diagenetic controls including the formation of quartz, pyrite and carbonate as cements, development of authigenic clays and dissolution of feldspar, quartz and mica grains. Thin section analysis indicates that compaction leads to the primary porosity reduction at the early stage. However, close contact of grains is rarely seen in samples. The contact relations of grains are main point contact, locally long to concavo-convex contact. These local changes of grains contact in some samples and the formation of fake matrix may have played significant role in the porosity destruction (Fig.6 C and D).

In Sokor1 sandstones cement of calcite, pyrite, quartz overgrowth and others strongly affect the reservoir quality. Calcite cement, especially the poikilitopic type (Fig.9 B and D) sit in pore spaces and blocked the pore throats which act as permeability reduction cement more than grain coating ones (quartz overgrowth). Thus, calcite may have different impacts on reservoir quality depending upon its cement morphology. It also improves the porosity of the studied sandstones by forming micropores when it alternates quartz grains and inter-grain matrix (Fig.20B) due to the effects of replacement.

The authigenic clays present in Sokor1 sandstones including mostly kaolinite followed by chlorite, illite and I/S mixed-layer. These clays occurred as rims around detrital grains, pore-lining and pore-filling cements and reduce porosity and permeability (Fig.13-15). Most kaolinite formed during the middle diagenesis and replaced feldspar grains as byproducts. It affects reservoir quality by occluding pore spaces where it occur as pore-filling cement (Fig.13) but also has a positive effect on reservoir by forming some inter-crystal pores and many relic pores (Fig.13A and B). The chlorite cement occurred as pore-filling and pore-lining clays. Developed grain-coating chlorite helps to retain primary porosity and permeability by retarding or inhibiting the precipitation of quartz overgrowth during burial (McBride 1989, Worden \& Morad 2003, Nguyen et al. 2013) as indicated in figure 11B and E). However, as its thickness increase, the graincoating chlorites can make the reservoir quality to be poorer because chlorite coatings will partially or completely fill the pores and significantly obstruct the pore throats (Fig.14).

Quartz overgrowths are known as an important reservoir quality deteriorating mechanism in both moderately to deeply buried petroleum reservoirs (Imam 1986, Ehrenberg 1993, Worden \& Morad 2000, 2003, Nguyen et al. 2013). The occurrence of quartz overgrowth in the analyzed samples is one of the most important porosity deteriorating cement, which occurred during the mesodiagenesis stage. At this stage, coating the detrital quartz grains, quartz overgrowth lead to decrease pore radii and then reducing porosity and permeability of the Sokor1 sandstones. Generally, it is accepted that aqueous pore fluids displacement by hydrocarbons can inhibit the progress of diagenetic reactions thereby stopping precipitation of quartz cement (Kantorowicz 1985, Emery et al. 1993, Worden et al. 1998, Kraishan et al. 2000, Heasley et al. 2000, Marchand et al. 2002, Molenaar et al. 2008). Therefore the overall lack of quartz cement in Sokor1 sandstones during the eodiagenesis stage could be in part attributed to early emplacement of oil. However, increase of temperature is commonly accepted as one of the main controls on quartz cementation in sandstone reservoirs which mostly begins at temperatures of about 90 $130^{\circ} \mathrm{C}$ (Gluyas et al. 1993a, Walderhaug et al. 2000). Morad et al. 2000 and Mohammed Bukar 2013 stated that quartz cement precipitation begins commonly at threshold temperature $>70^{\circ} \mathrm{C}$. In Sokor1 sandstones the lack of quartz cement during the eodiagenesis stage can thus be neatly explained by lower temperature (Fig.21) but not the effect of early emplacement of oil as it shows a continuous precipitation of quartz cement during the mesodiagenesis stage (Fig.22). In this study, we lack timing oil charge relative to quartz cementation information which will lead us to decide whether oil emplacement has influenced the diagenetic process of Sokor1 sandstones or not. There is quiet agreement that oil emplacement before commencement of quartz cementation or synchronous to quartz cementation will inhibit quartz overgrowth while oil charge after quartz cementation will have no effect on reservoir quality (Worden et al. 1998, Marchand et al. 2000, Barclay \& Worden 2000, Marchand et al. 2002, Molenaar et al. 2008). Therefore oil fill was a relatively late process in these studied sandstones.

Relating to reservoir quality, dissolution is the chief master of forming secondary porosity in Sokor1 sandstones. The dissolved intragranular pores, inter-granular pores and some of the oversized pores are borne with dissolution. It would also enlarge the primary pore to form mixed pores, which would improve the reservoir property. The dissolved detrital grains include feldspar, quartz, mica and intergrain muddy content and rock fragment. Reservoir quality is partly improved by dissolution.

\section{Conclusions}

The Sokor1 sandstones reservoirs are very fine to coarse grains, poor to moderately sorted, mostly quartz sandstone, lithic quartz-arenite and rarely lithic fedspathic quartz-arenite, belonging to a system of fluvial, deltaic and lacustrine deposits. Sokor1 sandstones have porosity and permeability values varying from a minimum of $11 \%$ to a maximum of $27 \%$ and a minimum of $14 \mathrm{md}$ to a maximum of $308 \mathrm{md}$ respectively.

Sokor1 sandstones have undergone stages A and B of eodiagenesis, and now they are experiencing stage A of mesodiagenesis. Diagenetic modifications experienced by Sokor1 sandstones during burial history include compaction, cementation and dissolution. Recognized cement types in these sandstones include calcite, clays, silica and pyrite, minor dolomite and siderite. At an early stage of diagenesis development of poikilitopic calcite cement and mechanical compaction causes loss of some primary porosity. Clay minerals identified in the Sokor1 sandstones including kaolinite, chlorite, illite and mixed-layer I/S. Out of these clays kaolinite is by far the most abundant followed by chlorite. The later, occur both as pore-filling and pore-lining cements and are causes of porosity loss in these sandstones. In some cases, chlorite appears to have locally prevented growth of quartz thus helping to preserve the porosity. The Sokor1 sandstones have decreasing smectite-illite ratios with increasing depth indicating the transformation effect of the clay minerals due to the change of the pore water chemistry and alkaline medium. In Sokor1 sandstone quartz cement develops only during mesodiagenesis stages indicating temperature control on diagenetic process. Thus oil emplacement was a relatively late process and has had no discernable role to play in porosity preservation

Dissolution of detrital grains is the principal mechanisms for secondary porosity developments in Sokor1 sandstones. The secondary porosity mainly derived from dissolution of detrital feldspar (most common), followed by quartz, mica and inter-grain muddy content. Dissolution is seen as an important constructive deagenetic process; pores produces by it plays a key role on improving the reservoir properties. 
Reservoir quality of Sokor1 Formation is predominantly controlled by sedimentation with main content of property of source materials (quartz) and sedimentary facies. The compaction and calcite cementation is weak, quartz overgrowth act as porosity destruction cement and clay minerals relates to the quality reservoir. The diagenesis is constructive to the reservoir in general, but its influence is limited.

\section{Acknowledgements}

The authors are indebted to the Director General of the "Direction Générale des Hydrocarbures" and CNPC Niger Petroleum S.A., who granted permission to provide SWC samples. They thank the Director of the "Direction de la Recherche Scientifique" and his colleagues in the "Ministère de l'Enseignement Supérieur de la Recherche et de l'Innovation" of Niger who authorized this research project. We gratefully acknowledge UNESCO/People's Republic of China (The Great Wall) Co-Sponsored Fellowships for financial support. Finally, the authors thank an anonymous reviewer from whom the manuscript was significantly improved following their constructive comments.

\section{References}

[1] Abouessa A \& Morad S, (2009) An integrated study of diagenesis and depositional facies in tidal sandstones: Hawaz Formation (Middle Ordovician), Murzuq Basin, Libya. J Pet Geo 32, 39-66. https://doi.org/10.1111/j.1747-5457.2009.00434.x.

[2] Álvarez-Iglesias P \& Rubio B, (2012) early diagenesis of organic-matter-rich sediments in ría environment: Organic matter sources, pyrites morphology and limitation of pyritization at depth. Estuarine, Coastal and Shelf Science 100, 113-123. https://doi.org/10.1016/j.ecss.2012.01.005.

[3] Anketel J.M (1996) Structural History of the Sirt Basin and its relationships to the Sabratah Basin and Cyrenaican Platform, Northern Libya. In Salem M.J, El-Hawat A.S \& Sbeta A.M (eds), The Geology of Sirt Basin Volume II, Elsevier, Amsterdam, pp. 57-87.

[4] Barclay S.A \& Worden R.H (2000) geochemical modelling of diagenetic reactions in a sub-arkosic sandstone. Clay Minerals, v. 35, no. 1, 57-67. https://doi.org/10.1180/000985500546729.

[5] Berger G, Lacharpagne J.C, Velde B, Beaufort D, \& Lanson B (1997) Kinetic constraints on illitization reactions and the effects of organic diagenesis in sandstone/shale sequences. Applied Geochemistry, 12, 23-35. https://doi.org/10.1016/S0883-2927(96)00051-0.

[6] Berner R.A (1981) Authigenic mineral formation resulting from organic matter decomposition in modern sediments. Fortschritte der Mineralogie $59,117-135$

[7] Binks R.M \& Fairhead J.D (1992) A plate tectonic framework for the evolution of the Cretaceous rift basins in West and Central Africa. In Ziegler P.A (Editor), Geodynamics of Rifting, Volume II Case History studies on Rifts: North and South America, Africa-Arabia. Tectonophysics 213, pp. 141-151. https://doi.org/10.1016/B978-0-444-89912-5.50034-X.

[8] Bliefnick D.M \& Kaldi J.G (1996) Pore geometry: control on reservoir properties, Walker Creek Field, Columbia and Lafayette counties, Arkansas. AAPG Bulletin 80, 1027-1044. https://doi.org/10.1306/64ED8C82-1724-11D7-8645000102C1865D.

[9] Boggs S.J (2009) Petrology of Sedimentary Rocks, 2nd ed. Cambridge University Press, Cambridge UK, p. 600. https://doi.org/10.1017/CBO9780511626487.

[10] Chang E \& Zung L.S (2017) 3D Reservoir Characterization of Field Deta, Termit Basin, Niger. Springer Singapore, 323-335, https://doi.org/10.1007/978-981-10-3650-7_28.

[11] Daly M.C, Chorowicz J \& Fairhead J.D (1989) Rift basin evolution in Africa: the influences of reactivated steep basement shear zones. Geological Society, London, Special Publications vol. 44, 309-334. https://doi.org/10.1144/GSL.SP.1989.044.01.17.

[12] Dutton S.P (2008) Calcite cement in Permian deep-water sandstones, Delaware Basin, west Texas: Origin, distribution, and effect on reservoir properties. AAPG Bulletin, v. 92, 765-787. https://doi.org/10.1306/01280807107.

[13] Ehrenberg S.N (1993) Preservation of anomalously high porosity in deeply buried sandstones by grain-coating chlorite: examples from the Norwegian continental shelf. AAPG Bull., 77, 1260-1286. https://doi.org/10.1306/BDFF8E5C-1718-11D7-8645000102C1865D.

[14] Emery D, Smalley P.C, Oxtoby N.H, Ragnarsdottir K.V, Aagaard P, Halliday A, Coleman M.L, \& Petrovich R (1993) Synchronous oil migration and cementation in sandstone reservoirs demonstrated by quantitative description of diagenesis [and discussion]: Philosophical Transactions of the Royal Society of London. Series A. Physical and Engineering Sciences, v. 344, no. 1670, 115-125. https://doi.org/10.1098/rsta.1993.0080.

[15] Fairhead J.D (1986) Geophysical controls on sedimentation in the African Rift Systems. In Frostick L.E, Renaut R.W, Reid I, \& Tiercelin J.J (Editors), Sedimentation in the African Rifts. Geol. Soc. London Spec. Publ. 25, 19-27. https://doi.org/10.1144/GSL.SP.1986.025.01.03.

[16] Fairhead J.D (1988) Mesozoic plate tectonic reconstructions of the central South Atlantic Ocean: The role of the West and Central African rift system. Tectonophysics, 155, 181-191 https://doi.org/10.1016/0040-1951(88)90265-X.

[17] Fairbridge R.W (1967) Phases of Diagenesis and Authigenesis. In Larsen G \& Chilingar C.V (Eds.) Diagenesis in Sediments. Elsevier, Amsterdam, pp. 91 - 125. https://doi.org/10.1016/S0070-4571(08)70841-0.

[18] Faure H (1966) Reconnaissance géologique des formations sédimentaires post paléaezoïques du Niger oriental. Memoires du Bureau de Recherches Géologiques et Minieres, vol. 47, 629 .

[19] Genik G.J (1992) Regional framework, structural and petroleum aspects of rift basins in Niger, Chad, and the Central African Republic. Tectonophysics 213 (1-2), 169-185. https://doi.org/10.1016/0040-1951(92)90257-7.

[20] Genik G.J (1993) Petroleum Geology of Cretaceous-Tertiary rift basins in Niger, Chad and Central African Republic. AAPG Bull. 77 (8), $1405-$ 1434. https://doi.org/10.1306/BDFF8EAC-1718-11D7-8645000102C1865D.

[21] Gluyas J.G, Grant S.M, \& Robinson A.G (1993a) geochemical evidence for a temporal control on sandstone cementation. In Horbury A. D \& Robinson A.G (eds.), Diagenesis and basin development. American Association of Petroleum Geologists Studies in Geology v. 36, 23-33.

[22] Guiraud R, Bellion Y, Benkhelil J \& Moreau C (1987) Post-Hercynian tectonics in Northern and Western Africa. Geological Journal vol. 22 thematic issue, 433-466. https://doi.org/10.1002/gj.3350220628.

[23] Guiraud R. \& Maurin J.C (1991) Le rifting en Afrique au Crétacé inférieur: synthèse structurale, mise en évidence de deux étapes dans la genèse des bassins, relations avec les ouvertures océaniques péri-africaines. Bull. Sot. Giol. Fr. 162, 811-823. https://doi.org/10.2113/gssgfbull.162.5.811.

[24] Guiraud R, Binks R.M, Fairhead J.D \& Wilson M (1992) Chronology and geodynamic setting of Cretaceous-Cenozoic rifting in West and Central Africa. In Ziegler P.A (Editor), Geodynamics of Rifting, Volume II Case History studies on Rifts: North and South America, Africa-Arabia. Tectonophysics, 713, pp. 227-234. https://doi.org/10.1016/B978-0-444-89912-5.50039-9.

[25] Guiraud R \& Maurin J.C, (1992) Early Cretaceous Rifts of Western and Central Africa: an overview. Tectonophysics 213, $153-168$. https://doi.org/10.1016/0040-1951(92)90256-6.

[26] Guiraud M (1993) Late Jurassic rifting-Early Cretaceous rifting and Late Cretaceous transpressional inversion in the Upper Benue basin (NE Nigeria). Elf Aquitaine Bull. 17 (2), 371-383.

[27] Harouna M \& Philp R.P (2012) Potential petroleum source rocks in the Termit basin, Niger. Journ. Petrol. Geol. 35 (2), $165-186$. https://doi.org/10.1111/j.1747-5457.2012.00524.x.

[28] Harouna M, Pigott J.D \& Philp R.P (2017) Burial history and thermal maturity evolution of the Termit Basin, Niger. Journ. Petrol. Geol. Vol. 40 (3), 277-297. https://doi.org/10.1111/jpg.12676.

[29] Heasley E.C, Worden R.H, \& Hendry J.P (2000) Cement distribution in a carbonate reservoir: recognition of a palaeo oil-water contact and its relationship to reservoir quality in the Humbly Grove field, onshore, UK. Marine and Petroleum Geology v. 17, no. 5, 639-654. https://doi.org/10.1016/S0264-8172(99)00057-4. 
[30] Imam B (1986) Scanning electron microscopy study of the quartz overgrowths within Neogene sandstones of Bengal Basin, Bangladesh. Journal of Geological Society of India 28, 407-413.

[31] Islam M.A (2009) Diagenesis and reservoir quality of Bhuban sandstones (Neogene), Titas Gas Field, Bengal Basin, Bangladesh. Journal of Asian Earth Sciences 35, 89-100. https://doi.org/10.1016/j.jseaes.2009.01.006.

[32] Kantorowicz J.D (1985) the origin of authigenic ankerite from the Ninian Field, UK North Sea. Letters to Nature v. 315 , $212-216$. https://doi.org/10.1038/315214a0.

[33] Kraishan G.M, Rezaee M.R \& Worden R.H (2000) Significance of trace element composition of quartz cement as a key to reveal the origin of silica in sandstones: an example from the Cretaceous of the Barrow sub-basin, Western Australia. In Worden R.H \& Morad S (eds.), Quartz cementation in sandstones. International Association of Sedimentologists Special Publications v. 29, pp. 317-332. https://doi.org/10.1002/9781444304237.ch21.

[34] Lakshtanov L.Z \& Stipp S.L.S (2010) Interaction between dissolved silica and calcium carbonate: 1. Spontaneous precipitation of calcium carbonate in the presence of dissolved silica. Geochimica et Cosmochimica Acta, Volume 74, Issue 9, 2655-2664, https://doi.org/10.1016/j.gca.2010.02.009.

[35] Lanson B, Beaufort D, Berger G, Bauer A, Cassagnabere A, \& Meunier A (2002) Authigenic kaolin and illitic minerals during burial diagenesis of sandstones: a review. Clay Minerals 37, 1-22. https://doi.org/10.1180/0009855023710014.

[36] Lanson B, Sakharov B.A, Claret F, \& Drits V.A (2009) Diagenetic smectite-to-illite transition in clay-rich sediments: A reappraisal of X-ray diffraction results using the multi-specimen method. American Journal of Science 309, 476-516. https://doi.org/10.2475/06.2009.03.

[37] Lan C, Yang M, Zhang Y (2015) Impact of sequence stratigraphy, depositional facies and diagenesis on reservoir quality: a case study on the Pennsylvanian Taiyuan sandstones, Northeastern Ordos Basin, China. Marine and Petroleum Geology, https://doi.org/10.1016/j.marpetgeo.2015.09.009.

[38] Liu B, Pan J, Wan L, Mao F, Liu J, Lu M, Wang Y, Chen Z, \& Jiang H (2012b) Polyphase rift evolution of the Termit Basin, eastern Niger: constraints from structural and sedimentary records. Geoscience 26 (2), 319-325.

[39] Liu B, Wan L.K, Mao F.J, Liu J.G, Lü M.S \& Wang Y.H (2015), Hydrocarbon potential of Upper Cretaceous marine source rocks in the Termit Basin, Niger. Journal of Petroleum Geology 38, 157-176. https://doi.org/10.1111/jpg.12604.

[40] Liu Bang, Guangya Zhang, Fengjun Mao, Jiguo Liu \& Mingsheng Liu (2017) Geochemistry and origin of Upper Cretaceous oils from the Termit Basin, Niger. Journ. Petrol. Geol. 40(2), 195-207. https://doi.org/10.1111/jpg.12672.

[41] Li Yingli, Jingong Cai, Mingshui Song, Junfeng Ji, \& Yujin Bao (2016) Influence of organic matter on smectite illitization: A comparison between red and dark mudstones from the Dongying Depression, China. American Mineralogist Vol. 101, 134-145. https://doi.org/10.1111/jpg.12672.

[42] Louis P (1970) Contribution géophysique à la connaissance géologique du bassin du lac Tchad. Paris, ORSTOM 2 (42), p. 312. https://doi.org/10.1180/000985500546585.

[43] Marchand A.M.E, Haszeldine R.S, Macaulay C.I, Swennen R \& Fallick A.E (2000) Quartz cementation inhibited by crestal oil charge: Miller deep water sandstone, UK North Sea. Clay Mineral, v. 35, no. 1, 201-210.

[44] Maurin J.C \& Guiraud R (1993) Basement control in the development of the Early Cretaceous West and Central African Rift System. Tectonophysics 228, 81-95. https://doi.org/10.1016/0040-1951(93)90215-6.

[45] McBride E.F (1989) Quartz cement in sandstones: A review. Earth Science Reviews 26, 69-112. https://doi.org/10.1016/0012-8252(89)90019-6.

[46] Mohammed Bukar (2013) does oil emplacement stop diagenesis and quartz cementation in deeply buried sandstone reservoirs. Thesis, University of Liverpool, pp. 1-270.

[47] Molenaar N, Cyziene J, Sliaupa S, \& Craven J (2008) Lack of inhibiting effect of oil emplacement on quartz cementation: Evidence from Cambrian reservoir sandstones, Paleozoic Baltic Basin. Geological Society of America Bulletin v. 120, no. 9-10, 1280-1295. https://doi.org/10.1130/B25979.1.

[48] Morad S (1986) Albitization of K-feldspar grains in Proterozoic arkoses and greywackes from southern Sweden. Neues Jahrbuch für Mineralogie Mh, 145-156.

[49] Morad S (1998) Carbonate cementation in sandstones: distribution patterns and geochemical evolution. In Morad S (Ed.), Carbonate cementation in sandstones. IAS Special Publication 26, pp. 1-27. https://doi.org/10.1002/9781444304893.ch1.

[50] Morad S, Ketzer J.M \& Deros L.F (2000) Spatial and temporal distribution of diagenetic alterations in siliciclastic rocks: implications for mass transfer in sedimentary basin. Sedimentology 47, 95-120. https://doi.org/10.1046/j.1365-3091.2000.00007.x.

[51] Moraes M.A.S \& De Ros L.F (1990) Infiltrated clays in fluvial Jurassic sandstones of Recôncavo Basin, northeastern Brazil. Journal of Sedimentary Research v. 60, no. 6, 809-819. https://doi.org/10.1306/212F928C-2B24-11D7-8648000102C1865D.

[52] Needham S.J, Worden R.H \& McIlroy D (2004) Animal-sediment interactions: the effect of ingestion and excretion by worms on mineralogy. Biogeosciences 1, 113-121. https://doi.org/10.5194/bg-1-113-2004.

[53] Needham S.J, Worden R.H \& McIlroy D (2005) Experimental production of clay rims by macrobiotic sediment ingestion and excretion processes. Journal of Sedimentary Research 75, 1028-1037. https://doi.org/10.2110/jsr.2005.078.

[54] Nguyen N.T.T, Jones S.J, Goulty N.R, Middleton A.J, Grant N, Ferguson A \& Bowen L (2013) The role of fluid pressure and diagenetic cements for porosity preservation in Triassic fluvial reservoirs of the Central Graben, North Sea. AAPG Bulletin 97, $1273-1302$. https://doi.org/10.1306/01151311163.

[55] Petters S.W (1978) Stratigraphic evolution of the Benue trough and its implications for the Upper Cretaceous paleogeography of West Africa. Journ. Geol. Vol. 86, 311-322 https://doi.org/10.1086/649693.

[56] Petters S.W (1981) Stratigraphy of Chad and Iullemmeden basins (West Africa). Ecologae Geologicae Helvetiae vol. 74, 139-159

[57] Rahman M.J \& McCann T (2012) Diagenetic history of the Surma Group sandstones (Miocene) in the Surma Basin, Bangladesh. J. Asian Earth Sci. 45, 65-78. https://doi.org/10.1016/j.jseaes.2011.09.019.

[58] Robert Ehrlich \& Edward L. Etris (1990) Physical relevance of pore types derived from thin section by petrographic image analysis. SCA conference paper number 90001, 1-28.

[59] Rossi C, Marfil R, Ramseyer K \& Permanyer A (2001) Facies-Related Diagenesis and Multiphase Siderite Cementation and Dissolution in the Reservoir Sandstones of the Khatatba Formation, Egypt's Western Desert. Journal of Sedimentary Research 71, 459-472. https://doi.org/10.1306/2DC40955-0E47-11D7-8643000102C1865D.

[60] Salman B, Robert H.L \& Linda B (2002) Anomalously high porosity and permeability in deeply buried sandstone reservoirs: origin and predictability. AAPG Bull. 86 (2), 301-28. https://doi.org/10.1306/61EEDABC-173E-11D7-8645000102C1865D.

[61] Sawlowcz Z (1993) Pyrite framboids and their development: a new conceptual mechanism. Geologische Rundschau 82, 148-156. https://doi.org/10.1007/BF00563277.

[62] Schäfer K, Kraft K.H, Hausler H \& Erdman J (1980) In situ stresses and paleostresses in Libya. In Salem N.J \& Busrewil M.T (Editors), Geology of Libya, Al-Fateh Univ, Tripoli (1981), pp. 907-922.

[63] Schmid S, Worden R.H \& Fisher Q.J (2004) Diagenesis and reservoir quality of the Sherwood Sandstone (Triassic), Corrib Field, Slyne Basin, west of Ireland. Marine and Petroleum Geology 21, 299-315. https://doi.org/10.1016/j.marpetgeo.2003.11.015.

[64] Schull T.J (1988) Rift basins of interior Sudan, petroleum exploration and discovery. AAPG Bulletin vol. 72, $1128-1142$. https://doi.org/10.1306/703C9965-1707-11D7-8645000102C1865D.

[65] Wan L, Liu J, Mao F, Lv M, \& Liu B (2014) The petroleum geochemistry of the Termit Basin, Eastern Niger. Mar. Pet. Geol. vol. 51, 167-183. https://doi.org/10.1016/j.marpetgeo.2013.11.006.

[66] Walderhaug O, Lander R.H, Bjorkum P.A, Oelkers E.H, Bjorlykke K \& Nadeau P. H (2000) Modelling quartz cementation and porosity in reservoir sandstones: examples from the Norwegain continental shelf. In: Worden R.H \& Morad S (eds.), Quartz cementation in sandstones. International Association of Sedimentologists, Special Publications v. 29, pp. 39-50. https://doi.org/10.1002/9781444304237.ch3. 
[67] Walker T.R (1962) Reversible Nature of Chert-Carbonate Replacement in Sedimentary Rocks. Geological Society of America Bulletin vol. 73, issue 2, 237, https://doi.org/10.1130/0016-7606(1962)73[237:RNOCRI]2.0.CO;2.

[68] Weger Ralf J, Gregor Eberli P, Gregor Baechle T, Jose Massaferro L, \& Yue-Feng Sun (2009) Quantification of pore structure and its effect on sonic velocity and permeability in carbonates. AAPG Bulletin v.93, no.10, 1297-1317, https://doi.org/10.1306/05270909001.

[69] Wei H, Roaldset E, Bjorøy M (1996) Parallel reaction kinetics of smectite to illite conversion. Clay Minerals 31, 365-376. https://doi.org/10.1306/05270909001.

[70] Wilson M. D \& Pittman E.D (1977) Authigenic clays in sandstones: recognition and influence on reservoir properties and paleoenvironmental analysis. Journal of Sedimentary Petrology v. 47, 3-31. https://doi.org/10.1306/212F70E5-2B24-11D7-8648000102C1865D.

[71] Wilson M.D (1992) Inherited grain-rimming clays in sandstones from eolian and shelf environments: their origin and control on reservoir properties: In Houseknecht D.W \& Pittman E.D (eds.), Origin, diagenesis, and petrophysics of clay minerals in sandstones. Society for Sedimentary Geology Special Publication v. 47, pp. 209-225. https://doi.org/10.2110/pec.92.47.0209.

[72] Worden R.H, Oxtoby N.H, \& Smalley P.C (1998) Can oil emplacement prevent quartz cementation in sandstones? Petroleum Geoscience v. 4, no. 2, 129-137. https://doi.org/10.1144/petgeo.4.2.129.

[73] Worden R.H \& Morad S (2000) Quartz cementation in oilfield sandstones: a review of the key controversies. Spec. Publi. Int. Assoc. Sedimentol. 29, 1-20. https://doi.org/10.1002/9781444304237.ch1.

[74] Worden R.H \& Morad S (2003) Clay minerals in sandstones: controls on formation, distribution and evolution. In Worden R.H \& Morad S (Eds.), Clay mineral Cements in Sandstones, 34. International Association of Sedimentologists Special Publications, pp. 3-41.

[75] Yuan G, Gluyas J, Cao Y, Oxtoby N.H, Jia Z, Wang Y, Xi K \& Li X (2015) Diagenesis and reservoir quality evolution of the Eocene sandstones in the northern Dongying Sag, Bohai Bay Basin, East China. Marine and Petroleum Geology (2015), https://doi.org/10.1016/j.marpetgeo.2015.01.006.

[76] Zanguina M, Bruneton A \& Gonnard R (1998) An introduction to the petroleum potential of Niger. Journ. Petrol. Geol. 21 (1), 83-103. https://doi.org/10.1111/j.1747-5457.1998.tb00647.x.

[77] Zhang J.L (2004) Diagenesis of lacustrine deltaic sandstone and its impact on reservoir quality. Acta Sedimentologica Sinica $22(2), 225-233$.

[78] Ziegler P.A (1992) Plate tectonics, plate moving mechanisms and rifting. In Ziegler P. A (Editor), Geodynamics of Rifting, Volume III Thematic Discussions. Tectonophysics 215, pp. 9-34. https://doi.org/10.1016/B978-0-444-89912-5.50044-2.

[79] Ziegler P.A (1988) Evolution of the Arctic-North Atlantic and the Western Tethys. Am. Assoc. Pet. Geoi. Mem. $43,198$. 